\title{
Ornamentation of dermal bones of Metoposaurus krasiejowensis and its ecological implications
}

\author{
Mateusz Antczak ${ }^{\text {Corresp., } 1}$, Adam Bodzioch ${ }^{2}$ \\ 1 Institute of Geology, Adam Mickiewicz University of Poznan, Poznan, Poland \\ 2 Department of Biosystematics, University of Opole, Opole, Poland \\ Corresponding Author: Mateusz Antczak \\ Email address: mateusz.antczak@amu.edu.pl
}

Background. Amphibians are animals strongly dependent on environmental conditions, like temperature, water accessibility, and reservoir trophy. Thus, they can be used in modern palaeoenvironmental analysis, reflecting ecological condition of the biotope.

Methods. To analyse the observed diversity in the temnospondyl Metoposaurus krasiejowensis from Late Triassic deposits in Krasiejów (Opole Voivodeship, Poland), the characteristics of the ornamentation (such as grooves, ridges, tubercules) of 25 clavicles and 13 skulls were observed on macro- and microscales, including the use of a scanning electron microscope for high magnification. The different ornamentation patterns found in these bones have been used for taxonomical and ecological studies of inter- vs intraspecific variation.

Results. Two distinct types of ornamentation (fine, regular and sparse, or coarse, irregular and dense) were found, indicating either taxonomical, ecological, individual, or ontogenetic variation, or sexual dimorphism in Metoposaurus krasiejowensis.

Discussion. Analogies with modern Anura and Urodela, along to previous studies on temnospondyls amphibians and the geology of the Krasiejów site suggest that the differences found are rather intraspecific and may suggest ecological adaptations. Sexual dimorphism and ontogeny cannot be undoubtedly excluded, but ecological variation between populations of different environments or facultative neoteny (paedomorphism) in part of the population (with types of ornamentations being adaptations to a more aquatic or a more terrestrial lifestyle) are the most plausible explanations. 


\title{
1 Title: Ornamentation of dermal bones of Metoposaurus krasiejowensis and its 2 ecological implications.
}

\section{Mateusz Antczak ${ }^{1}$, Adam Biodzioch ${ }^{2}$}

\author{
$4 \quad{ }^{1}$ Institute of Geology, Adam Mickiewicz University of Poznań, Poznań, Poland \\ 62 Department of Biosystematics, University of Opole, Opole, Poland

8 Abstract:

9 Background. Amphibians are animals strongly dependent on environmental conditions, like 10 temperature, water accessibility, and reservoir trophy. Thus, they can be used in modern 11 palaeoenvironmental analysis, reflecting ecological condition of the biotope.

12 Methods. To analyse the observed diversity in the temnospondyl Metoposaurus krasiejowensis from 13 Late Triassic deposits in Krasiejów (Opole Voivodeship, Poland), the characteristics of the ornamentation 14 (such as grooves, ridges, tubercules) of 25 clavicles and 13 skulls were observed on macro- and 15 microscales, including the use of a scanning electron microscope for high magnification. The different 16 ornamentation patterns found in these bones have been used for taxonomical and ecological studies of 17 inter- vs intraspecific variation.

18 Results. Two distinct types of ornamentation (fine, regular and sparse, or coarse, irregular and dense) 19 were found, indicating either taxonomical, ecological, individual, or ontogenetic variation, or sexual 20 dimorphism in Metoposaurus krasiejowensis.

21 Discussion. Analogies with modern Anura and Urodela, along to previous studies on temnospondyls amphibians and the geology of the Krasiejów site suggest that the differences found are rather intraspecific and may suggest ecological adaptations. Sexual dimorphism and ontogeny cannot be undoubtedly excluded, but ecological variation between populations of different environments or facultative neoteny (paedomorphism) in part of the population (with types of ornamentations being adaptations to a more aquatic or a more terrestrial lifestyle) are the most plausible explanations.

\section{Introduction}

29 The fossil assemblage from the Late Triassic deposits in Krasiejów (SW Poland, near the city of Opole) is 30 a unique discovery. Excavations carried out since 2000 have revealed new data concerning the evolution 
31 of terrestrial Triassic faunas. In Krasiejów, although the remains of several groups of fish and archosaurs 32 were also found (e.g. Dzik \& Sulej, 2007, 2016; Brussatte et al., 2009; Piechowski \& Dzik, 2010; Sulej, 33 2010; Skrzycki, 2015; Antczak, 2016; Dzik \& Sulej, 2016; Antczak \& Bodzioch, 2018), fossils of large 34 temnospondyl amphibians described as Metoposaurus krasiejowensis (Sulej, 2002; species name revised 35 by Brusatte et al., 2015) were the most abundant.

36 Despite many years of study, new data are still being collected and some aspects of the anatomy and 37 ecology of extinct animals are being reinterpreted (e. g. Konietzko-Meier \& Klein, 2013; Konietzko-Meier 38 \& Sander, 2013; Gruntmejer, Konietzko-Meier \& Bodzioch, 2016; Konietzko-Meier et al., 2018), along 39 with the age of bone accumulations in Krasiejów (Lucas, 2015; Szulc, Racki \& Jewuła, 2015) and their 40 origin (Bodzioch \& Kowal-Linka, 2012). One aspect not described in detail is the morphology of metoposaurid dermal bone ornamentation, which was assumed to be randomly variable (Sulej, 2007) or similar in all representatives of the species, as suggested by Witzmann et al. (2010). The aim of this paper is to describe in detail, on macro- and microscales, the ornamentation of metoposaurid clavicles and skull bones, in order to examine its variation and to test whether or not it is the same in all specimens. A thorough probe of skeletal elements from one site shows that differences between specimens are not random.

\section{Material and methods}

The size, number, shape, placement, and other features of the ornamentation elements of metoposaurid clavicles (and as a remark: skull bones) were analysed. The material derived from the 'Trias' site at Krasiejów (SW Poland; Fig. 1). The fine-grained (mudstones and claystones) Late Triassic (Carnian, according to Dzik \& Sulej, 2007; Lucas, 2015; Norian, according to Szulc, 2005; 2007; Szulc, Racki \& Jewuła, 2015) deposits can be divided into three units (e.g. Gruszka \& Zieliński, 2008), in which two bone-bearing horizons occur. The lower horizon, the product of a mudflow deposition that probably occurred during a heavy rainy season, is especially abundant in fossils, including Metoposaurus krasiejowensis. The upper horizon was described within massive claystones covering palaeochannels of low-energy meandering river. Within the upper horizon remains of Silesaurus and Polonosuchus were found (Dzik \& Sulej, 2007).

To test the diversity of dermal bone ornamentation in metoposaurids from Krasiejów, 25 clavicles (UOPB1152-1176) and 13 skulls (working numbers counting from the excavation site: UO/PP01-20)

61 were analysed in detail (Tables 1-3). Morphometric measurements for 21 skulls were also taken (Table

62 4). The clavicles were removed during the excavation and are held in the Opole University collection, 
63 while the skulls were present in situ in the palaeontological pavilion (also part of Opole University) at the

64 digging site in Krasiejów; one of them is housed in the Faculty of Geographical and Geological Sciences

65 Museum of Earth at the Adam Mickiewicz University in Poznań (uam/mz/586). As an outgroup skull and clavicle of Cyclotosaurus (ZPAL/AbIII/397) from Museum of evolution in Warsaw were examined.

All described specimens were found in the lower bone-bearing horizon.

The characteristics of the polygonal and radial structure of clavicles were described, using over 20 features, including some of the 12 used by Witzmann et al. (2010). Observations are shown in Table 1, which groups similar features and assigns them numerical values.

Observations were made macroscopically and microscopically using an Olympus SZ61 binocular microscope, a Zeiss SteREO microscope, and a DIGEYE digital microscope. Fragments of 10 clavicles were analysed using a Hitachi S-3000N Scanning Electron Microscope. Samples were taken from the same parts of the clavicles: radial ornamentation in the posterior region of the bone, several centimetres behind the ossification centre. Samples were sprayed with gold and palladium and observed under a high vacuum at the Institute of Plant Protection - National Research Institute in Poznań. One sample was observed using a Hitachi S-3700N at the SEM-EDS Laboratory of Faculty of Geographical and Geological Science of Adam Mickiewicz University in Poznań.

Selected macroscopic features of skull bones were described only as a result of the fact that the presentation of bones in situ makes it impossible to describe micro- or sub-microscopic features. Not all such features were described. Dermal bone ornamentation can be divided into radial ornamentation, composed of parallel or radial ridges without transverse ridges, and polygonal ornamentation, composed of short ridges connected to form polygons. The vertices of the polygons are called nodal points. The polygonal sculpture area is the ossification centre, the part of the bone that ossifies first. Near the ossification centre is an anterior appendix. Polygons may be hexagonal, pentagonal, rectangular, or irregular in shape. Polygons joined by means of a missing ridge are called multipolygons (Fig. 2). All measured features are listed in Table 1. SEM observations included features of the surface of the ridges, such as the number of foramina and degree of ridge roughness (Fig. 3). The possible relative individual ages of the clavicle specimens were determined using the method based on ornament development, presented by Witzmann et al. (2010) and improved by Zalecka (2012).

92 For testing the significance of described variation statistical test were used. At first Shapiro-Wilk test for 93 testing normality of the data, then respectively test $F$, test $T$ and test $U$. Test $F$ was used if both 94 compared samples had normal distribution. Test F was used for testing the variance. If the difference 
95 96

98

99

101

102

103

104

105

106

107

108

109

110

111

112

113

114

115

116

117

118

119

120

121

122

123

124

between variances were not significant, test T was used. If the variances were significantly different, or samples not had normal distribution, test $U$ was used. If the final test gave the $p$-value (probability value) less than 0.05 it means that samples are significantly different.

\section{Observations}

\section{Diagnosis: Clavicles}

Clavicles of metoposaurids from Krasiejów showed diversity in ornamentation, having fine, regular and sparse, or coarse, irregular and dense sculpture. After this observation, the clavicles ornamentation was examined in greater detail.

Some of the analysed features show random variation or none; however, most are distributed bimodally. Therefore, in every specimen one or the other set of characteristics occur, and two types of ornamentation can be distinguished (Tc1 and Tc2).

Specimens classified as type 1 (Tc1) are characterised by more regular ornamentation of the clavicles: the borders of the ossification centre (polygonal sculpture) are easily recognised, the polygonal sculpture field has a square shape, and the ornamentation is fine and sparse, moreover, nodal points are more pronounced, being broader and higher than the ridges that connect them, ridges are usually narrow, hexagons with a low level of size diversity dominate, multipolygons are rare, clavicles, even when large, are relatively thin; the anterior process of the clavicle is usually flat and small (Fig. 2); while specimens classified as type $\mathbf{2}$ (Tc2) posses less regular ornamentation: the borders of the ossification centre (polygonal sculpture) are difficult to recognise, the polygonal sculpture field is characterised by a rectangular shape (elongated posteriorly), and the ornamentation is thicker and denser, moreover, nodal points are only slightly broader and higher than the ridges that connect them, ridges are wide or narrow, often rounded, polygons are more often pentagonal or irregular, multipolygons are frequent, clavicles are relatively thick, independently of their size or age, and the anterior process is usually round in cross section and expanded (Fig. 2).

Both types of Metoposaurus dermal bones ornamentation are however distinct from Cyclotosaurus sculpture (Sulej \& Majer, 2005). Cyclotosaurus can be characterised by relatively large and rhomboidal polygons (sometimes elongated pentagons). Radial ornament is very sparse (spaces between ridges are wide). Ossification centre is large and posses distinct borders, but the polygon number is low (25). Clavicle is thick. Ridges are round and thick (ZPAL/AbIII/397, personal observation). 
125 The distribution of certain characteristics according to the relative individual age or type assignment is

126 presented in figures 3-7. All plots show bimodal distribution of the parameters, which are independent

127 of estimated relative individual age of specimens. UOPB1165 (Fig. 2) specimen not fitting any of this

128 types might be the representative of a different taxon, although it was the most incomplete specimen,

129 which may affect the result of its description. Some features were not described for this specimen i. e.

130 borders and shape of the ossification centre or radial ridges character (Table 1). Estimated size of the

131 complete specimen is small, but the ossification degree is high. Its possible assignment to species other

132 than M. krasiejowensis would be difficult without other findings.

133 In table 5, the results of conducted statistical test are presented - F and T or $U$, dependent on the data

134 distribution. Considering described types as different groups, quantitative and qualitative data shows

135 that they differ significantly $(\alpha=0.05)$.

136

\section{Micro/nanoscale}

138 Two types can also be distinguished according to the micromorphology of the ornamentation ridges and

139 bone structure in cross-section. Clavicles assigned to type 1 do not possess striations (or striations, if

140 present, are barely visible and sparse) and possess a low number of small capillary foramina at the

141 slopes of the ridges (less than 7 per $100 \mu \mathrm{m}^{2}$ ). Usually they also have less than one foramen per $1 \mathrm{~mm}$ of

142 ridge length and no distinct bumps or roughness at the top of the ridge (Figs. 8-9, Table 2). In cross-

143 section they possess growth marks in close proximity within poorly vascularised upper cortex (Fig. 8).

144 Clavicles assigned to type 2 possess striations on the ridges and a greater number of small foramina 145 (more than 7 per $100 \mu \mathrm{m}^{2}$ ). Usually they also have more than one foramen per $1 \mathrm{~mm}$ of ridge length and 146 distinct bumps and roughness at the top of the ridge (Figs. 8-9, Table 2). In cross-section they possess 147 growth marks separated by well-vascularised zones (Fig. 9). This difference in histological patterns is 148 analogous to different growth strategies described for the example of long bones (Teschner, Sander \& 149 Konietzko-Meier, 2017).

150 


\section{Remarks on other dermal bones}

\section{Skulls}

154 Bimodal differences were found also in skulls (Table 3), which have been divided in the Ts1 and Ts2 155 types. The main characteristic of ornamentation of ossifying centers resembles either Tc1 (large, 156 hexagonal, sparse polygons, almost no multipolygons; 6 specimens; Ts1) or Tc2 (small, irregular and 157 dense polygons with common multipolygons; 7 specimens; Ts2). There is also a visible difference in the

158 spatial distribution of polygonal and radial ornamentations between Ts1 and Ts2 (Fig. 10). In the first 159 type, radial pattern covers large areas of the skulls roof in their both preorbital and postorbital 160 (postfrontal, postorbital, supratemporal bones) parts, while in the second it occupies much smaller 161 areas.

162 An important fact is that the skulls classified as Ts2 are relatively small (averaging $28 \mathrm{~cm}$ in length) in 163 contrast to Ts1 skulls (averaging $35 \mathrm{~cm}$ in length). However, this was not a rule. Among analysed skulls 164 were two $35 \mathrm{~cm}$ in length (UO/PP04, $35 \mathrm{~cm}$; UO/PP18, $35.4 \mathrm{~cm}$ ) with different ornamentation types (Fig. 165 10, Tables 3, 4).

\section{Discussion}

\section{Reasons for the observed variation in dermal bone ornamentation}

169 The presented diversity in the dermal bone ornamentation of $M$. krasiejowensis may be the result of species diversity, ontogenetic diversity, sexual dimorphism and individual variation, different habitats of two populations or facultative neoteny.

1. Species diversity. Given that no differences were found in axial and appendicular skeleton characteristics - all analysis described metoposaurid material as one species, M. krasiejowensis (i. e. Gądek, 2012; Konietzko-Meier \& Klein, 2013; Konietzko-Meier \& Sander, 2013; Teschner, Konietzko-Meier \& Sander, 2017) or in dermal bone measurements, it is also unlikely that the described differences in the analysed material represent differences between two species. Shape and ornamentation pattern of the clavicles (both described types) is strongly distinct from M. algavrensis or Cyclotosaurus intermedius (Figs. 4-6) (Sulej \& Majer, 2005; Brusatte et al., 2015). Only the distinct character of the UOPB1165 specimen observed on the bivariate plots of countable features might suggests that this specimen does not belong to the same species. The occurrence of some other taxon is possible because of the redeposited character of the fossils. Moreover, in skulls (both types - Ts1 and Ts2), the prepineal part of the parietals is short and 
the expansion angle of the sutures separating the parietal from the supratemporal vary between 19 and $26^{\circ}$ which is characteristic of $M$. krasiejowensis instead of $M$. diagnosticus (longer prepineal part and parietal expansion angle being around 13\%) (Sulej, 2002) (Fig. 11). Also relatively narrow shape of the skulls and shape of the sutures (i. e. between frontals and narials or parietals) is typical of $M$. krasiejowensis, being distinct from $M$. diagnosticus, $M$. algavrensis (Brusatte et al., 2015) (Fig. 11) or Cyclotosaurus (ZPAL/AbIII/397). According to this all skull specimens belong to Metoposaurus krasiejowensis. As only one species ( $M$. krasiejowensis) can be described considering skulls, and only this species was described in Krasiejów during over 15 years of studying metoposaurid material, it seems justified to consider all of the clavicles as belonging to M. krasiejowensis. With possibly one exception - UOPB1165.

2. Ontogenetic diversity. According to Witzmann et al. (2010), all described specimens belongs to adult individuals, as they all can be assigned to the last stage of sculpture development (Witzmann et al., 2010: fig. 6E). Although singular features may be connected with the age of the specimen, the method of determination of relative age for clavicles (youngest, intermediate, and oldest stages) based on the number of partition walls within the radial ornament shows that most of the analysed features, along with bone thickness, are not connected in this way. The youngest specimens possessed no partition walls between radial ridges. An intermediate stage was represented by specimens with developing partition walls within radial ornaments, and the oldest specimens possessed many well-developed partition walls between radial ridges. Additionally, clavicles described as the oldest stage, are the largest ones (UOPB1152 $19,5 \mathrm{~cm} x$ $9,7 \mathrm{~cm}$, UOPB1164 $20 \mathrm{~cm} \times 9 \mathrm{~cm}$ ), while the youngest are usually of small size (UOPB1166 $\sim 12 \mathrm{~cm}$ x 6cm, UOPB1171 10cm x 5cm).

Unfortunately the histology of dermal bones cannot be used to determine the exact individual age, as different cross sections of the same bone reveals different stage of remodelling and counting the growth marks is unreliable (Gruntmejer, personal communication; Konietzko-Meier et al., 2018; Figs. 8-9). The diversity of skull sizes assigned to different types also argues against ontogenetic diversity. Relatively small skulls possess more polygonal (adult; Witzmann et al., 2010) ornament than the largest skulls. In addition, there are no differences in the ratio of skull portions according to size; whereas in the metoposaurids, in the younger specimens, the orbits are placed further back on the skull relative to its length (Davidow-Henry, 1989), i.e. the area between orbits grew faster in temnospondyls than the orbits themselves. Polygon characteristics also indicate the adult stage in all skull specimens. Rinehart et al. (2008) and 
215

216

217

218

219

220

221

222

223

224

225

226

227

228

229

230

231

232

233

234

235

236

237

238

239

240

241

242

243

244

245

246

Lucas et al. (2010) also suggest that all individuals are adults. Sulej (2002) suggests that size of the clavicle depends on the age and recognized several clavicles of different size as an ontogenetic sequence. Nevertheless, this ontogeny cannot be used to explain ornamentation variety, as the two types of sculpture occur in both small and large specimens. The differentiation is also not the same as in the Rotten Hill, where age differences were proposed (Lucas et al., 2016). There are no size classes that can be correlated with sculpture variety in clavicles. In skulls, specimens assigned to type 2 are usually smaller, with exception of UO/PP18 (Table 4, Fig. 12, 13).

3. Sexual dimorphism. In the described material there is lack of dimorphism in the shape of the skulls (Urban \& Berman, 2007), clavicles or dentition (Kupfer, 2007). The location of clavicles (under the skin and on the ventral side of the body) and discussed function of the ornamentation excludes its role as 'display structures' in mating rituals (Kupfer, 2007) in contrast to i. e. Zatrachys serratus were spinescence and shape of the skull (rostrum) were considered as sexual dimorphism (Urban \& Berman, 2007). Different growth strategy seen in clavicles (Figs. 8-9), skulls (Gruntmejer, personal communication) and long bones (Teschner, Sander \& Konietzko-Meier, 2017) ('seasonal' growth marks separated by vascularised zones or slower growth with growth marks in close proximity within poorly vascularised bone) rather do not indicate different sexes, but was ecologically controlled.

4. Individual variation. The existence of two distinct ornamentation types with no intermediate patterns (Fig. 3-7) may support different ecological adaptations (see below) rather than individual variation as the only reason of diversity.

5. Different habitats. Morphology of the dermal sculpture and vascularisation are not separable. Regularity of the ornamentation reflects the mode of life of temnospondyls to a certain degree. The coarser ornament, more pronounced ridges and irregularity is characteristic of rather terrestrial taxa (i. e. Seymouria, Eryops, see: Witzmann et al., 2010) - T2, while irregular sculpture represents rather aquatic animals (Witzmann et al., 2010) - T1. The variety seen within M. krasiejowensis allows expanding this conclusion, showing that the ecological difference (listed features) can be observed within one species.

Metamorphosis is a hormonally induced and controlled process; thus, its results might be morphologically unequal even in closely-related taxa (Fritzsch, 1990; Norris, 1999) or within taxa (Rafiński \& Babik, 2000; Pogodziński, Hermaniuk \& Stępniak, 2015). Because of this and the fact that amphibians, as animals very closely connected with the environment, are phenotypically plastic 
247 (examples below), the morphological diversity of the analysed material may be a result of differences

248 between ecologically separated populations (geographic separation). Ecological separation of animals

249 which remains are deposited in one bone-bed is possible, because of the bone-bed character (material 250 partially redeposited, possibly from distant area, and partially local). Redeposition from different 251 environments is suggested by the variant infill succession in the pore system and trace elements 252 contents in the individual remains (Bodzioch \& Kowal-Linka, 2012; Bodzioch, 2015). The more aquatic 253 population might have lived at a different site - fossils are redeposited and material might be 254 transported even from Variscian Upland according to isotopic analysis of Konieczna, Belka \& Dopieralska 255 (2015). Thus, geographical separation is a probable explanation, because the different ecological 256 character of specimens might suggest that the two populations did not interbreed with each other. Time 257 separation is also plausible. Some clavicles can be reworked more than once, being removed from older 258 level than those which provided the skulls, which often seem to have a better preservation.

259 The more terrestrial population probably lived at the site, where environment resembles modern Gilgai 260 relief of Texas or Australia (Szulc, Racki \& Jewuła, 2015) while more aquatic populations lived at some 261 distance in larger reservoir(s).

262 Although the presence of some large skulls with no abrasion or weathering does not support transport 263 from a distant area, a brief transport however is plausible as the teeth in the mandibles and upper jaws 264 are usually lost (Lucas et al., 2010).

265 Other possibility is temporal diversity - gradually changing conditions of environment parallel with amphibian morphology/behaviour adaptation, however some intermediate ornamentation patterns should have been noticed in that case - see 'individual variation'.

6. Facultative neoteny (paedomorphism). Explanation assuming the same environmental differences between described morphotypes, but within a single population. The Late Triassic Krasiejów environmental conditions (dry and rainy season with possible periodic lack of food) may have even contributed to the formation of a neotenic population (Duellman \& Trueb, 1986; Safi et al., 2004; Frobisch \& Schoch, 2009). However, evidence of larval structures (i.e. branchial ossicles) in adult metoposaurids from Krasiejów is lacking. Nevertheless, facultative neoteny is possible (Motyl, 2008), as shown by the more radial (juvenile) sculpture on the large skulls of Ts1 (Witzmann et al. 2010). Facultative neoteny can be observed in several extant taxa i. e. Ambystoma talpoideum with aquatic paedomorphic adults and terrestrial metamorphic adults (Whiteman, Krenz \& Semlitsch, 2005). Breeding between such morphs is less common than within morphs, because paedomorphic adults begin to breed 
earlier (Krenz \& Sever, 1995; Whiteman \& Semlitsch, 2005). In this case M. Krasiejowensis Type $2(T c 2, T s 2)$ reflects metamorphic adults that transform into somewhat terrestrial, while Type 1

281

282

283

284

285

286

287

288

289

290

291

292

293

\section{4}

295

296

297

298

299

300

301

302

303

304

305

306

307

308

309

(Tc1, Ts1) reflects (partially) paedomorphic aquatic adults. This is possible because larval development is dependent on the environmental conditions. In Late Triassic Krasiejów dry and rainy seasons occurred which is known thanks to the versicolor nature of claystone and faunal composition with i. e. dipnoans (Szulc, 2005; 2007; Skrzycki, 2015). Associated with these changes in water-level, food availability, living space, and competition (Ghioca-Robrecht, Smith \& Densmore, 2009) may have influenced the preferred lifestyle. Metamorphosis into terrestrial or paedomorphic aquatic form is in this case the response to the individual expected success in the environment (Wilbur \& Collins, 1973; Whiteman, 1994; Michimae \& Wakahara, 2002) controlled by endocrine signals (Pfennig, 1992). Facultative neoteny in metoposaurids may occur in a single population (no geographical separation is needed) - spatial separation of morphs may occur instead, with the paedomorphic concentrating in deeper habitats (Whiteman $\&$ Semlitsch, 2005).

\section{Ornamentation and lifestyle}

The environmental differentiation is the most likely explanation regardless of whether caused by facultative neoteny or existence of two ecological types. Thus, described ornamentation types reflect more aquatic (Type 1) and more terrestrial (Type 2) morph of Metoposaurus krasiejowensis. In modern limbless serpentine amphibians (Gymnophonia: Apoda) and lizard-like salamanders (Caudata: Urodela), larvae resemble miniature adult specimens. Metamorphosis is gradual and there is little reorganisation of body plan (Zug, 1993). In fossil amphibians, body plan reorganisation was also minimal and rather gradual (Boy, 1974, 1988, 1990; Schoch, 2002, 2004), although its rate (trajectory: Schoch 2010) might differ between taxa depending on their habitat (Schoch, 2009). This is also the cause that there are no other features suggesting more aquatic or more terrestrial lifestyle. Such changes, like differences in lateral line morphology, require more 'evolutionary effort', while changes in ornamentation are probably fast, reversible and do not require genetic changes (Rafiński \& Babik, 2000; Babik \& Rafiński, 2000).

Typically aquatic taxa are characterised by slow changes (low trajectory), sometimes with incomplete ossification of the pelvic region and limbs (last stages of ontogenetic trajectory). Terrestrial taxa are characterised by faster metamorphosis (high trajectory, with particular phases condensed within a short 
310 period of time), including final phases (limb ossification) enabling locomotion on land. The trajectory of

311 semi-aquatic taxa lies between the two above-mentioned types.

312 This is an example of heterochrony. The length and composition of the temnospondyl ontogenetic

313 trajectory is ecologically controlled (Schoch, 2010). Metamorphosis in this case might be described as

314 extreme heterochrony, because many phases are condensed within a short time span (Alberch, 1989).

315 Ontogenetic trajectory and the morphology of adult specimens and their sizes may differ between

316 various environments inhabited by representatives of the same taxon (Schoch, 2010). There are several

317 examples of such diversity, such as differences observed in the length of the hind limbs of modern frogs

318 (Schmidt, 1938; Dubois, 1982; Emerson, 1986; Emerson, Travis \& Blouin, 1988; Rafiński \& Babik, 2000)

319 and the morphology of extinct temnospondyls: the ontogenetic rate and dentition of Apaeton (Schoch,

320 1995); the size of Micromelerpeton (Boy \& Suess, 2000; Schoch, 2010); the morphology of

321 Sclerocephalus (Schoch, 2010); the branchiosaurids (Werneburg, 1991, 2002; Werneburg, Ronchi \&

322 Schneider, 2007); and the plasticity of the plagiosaurid Gerrothorax (Schoch \& Witzmann, 2012; Sanchez

323 \& Schoch, 2013). Polyphenism (environmentally controlled polymorphism) exists in a wide range of

324 extant taxa (Roff, 1996) in adults (Whiteman, Krenz \& Semlitsch, 2005) and tadpoles (Collins \& Cheek,

325 1983; Pfennig, 1990; 1992; Walls, Belanger \& Blaustein, 1993; Nyman, Wilinson \& Hutcherson, 1993;

326 Michimae \& Wakahara, 2002; Pfennig \& McGee, 2010).

327 Dimorphism in bone characteristics of metoposaurids from Krasiejów can be seen in dermal bones as

328 well as in non-dermal skeletal elements from Krasiejów. Two types connected with growth trajectory

329 were seen in histological observations of metoposaur skulls (Gruntmejer, personal communication),

330 humeri (Teschner, Sander \& Konietzko-Meier, 2017), and the morphology of femora (Konietzko-Meier \&

331 Klein, 2013).

332 New facts about metoposaurids from Krasiejów show that they were not fully aquatic animals. 3D

333 computational biomechanics analysis of the skull of Metoposaurus show that it was capable of biting

334 prey in the same manner as semi-aquatic and terrestrial animals like Cyclotosaurus or modern crocodiles

335 (Gruntmejer, Konietzko-Meier \& Bodzioch, 2016; Fortuny, Marcé-Nogué \& Konietzko-Meier, 2017;

336 Konietzko-Meier et al., 2018).

337 The described diversity is consistent with the experiment of Schoch (1995) and the results of Werneburg

338 (2002) and Schoch (2010). One of the Metoposaurus ornamentation types from Krasiejów (T2) thus

339 represents a more terrestrial form (associated with the more variable and unstable environment of a

340 river or a small lake or the metamorphic adult form of facultative neotenic population), while the other

341 represents forms more closely related to water (a large lake habitat or partially paedomorphic aquatic 
342 adults) (T1) (ecological populations - as stated by Witzmann et al., 2010; but described as species-

343 specific; neoteny as described by Whiteman, Krenz \& Semlitsch, 2005).

344 The adaptations in T2 favouring a more terrestrial lifestyle are:

345 a) The increased mechanical strength of the bones (Rinehart \& Lucas, 2013) (coarser, denser, 346 irregular sculpture, thicker clavicles);

347

b) Protection from a greater number of blood vessels, improving thermoregulation (Gądek, 2012) (denser sculpture, more numerous polygons and radial rows, more numerous microforamina);

c) Stronger integration of bone and skin, which is thicker in terrestrial amphibians and exfoliates (Zug, 1993; Schoch, 2001) (coarser, denser sculpture, microstriations);

d) Stronger connection of the pectoral girdle elements and, potentially, limbs (expanded anterior projection of the clavicle);

e) Faster growth revealed by histological structure (growth marks separated by zones of highly vascularised bone).

The more terrestrial character of one of the population may also be proved by:

f) Faster (at younger age) metamorphosis revealed by smaller skulls;

g) The length of limb bones not correlated with individual age (Teschner, Sander \& Konietzko-

The dimorphic character of clavicles described herein and the two growth patterns of dermal and long bones (humeri) (Teschner, Sander \& Konietzko-Meier, 2017) suggest that the ontogeny of specimens assigned to Metoposaurus krasiejowensis could have proceeded via a different growth rate and time span of metamorphosis, caused by differing environmental conditions. The similar number of specimens from both populations (Tc1/Tc2 - 44\%/56\% and Ts1/Ts2 - 53\%/47\%) suggests stable populations. Apart from dermal bone ornamentation, the degree of ossification and variation in skull sizes divides metoposaurids into two groups. Smaller skulls occur in the more terrestrial type, as in Micromelerpeton from Germany, where smaller specimens represent an unstable lake environment (Boy \& Sues, 2000). The described type $\mathrm{T} 2$ reflects a more terrestrial or riparian habitat, where environmental conditions are variable and amphibians are forced to change their dwellings more often (migration between watercourses or 'stream-type' small, drying lakes; Werneburg, Ronchi \& Schneider, 2007). It does not 
373 migrate between rivers and lakes by 'pond-hopping' (Zug, 1993). The first type reflects a more stable

374 habitat, possibly a large lake, where animals are not forced to migrate ('pond-type'; Werneburg, 2007).

375 Geological, sedimentological, and other analysis of the Krasiejów site shows that both of these habitats

376 - episodic rivers and ponds at the excavation site and a large reservoir in close proximity - may have

377 occurred there (redeposited charophytes and Unionidae bivalves; Szulc, 2005; 2007), and that

378 conditions changed over time (Dzik \& Sulej, 2007; Gruszka \& Zieliński, 2008; Bodzioch \& Kowal-Linka,

379 2012). Differences in dermal bone ornamentation constitute an adaptive answer to changes in the

380 environment (temperature, water level, food availability) over time or to geographical differentiation of

381 habitats, i. e. faster metamorphosis (at smaller size) as an answer to higher temperatures; or

382 metamorphosis into terrestrial adult vs. transformation into aquatic paedomorphic individuals.

383 Rapid changes in the ornamentation morphology in one population (or part of the population, when 384 weather conditions favour such solution) are possible because they are the effects of hormonally 385 induced metamorphosis. The water temperature in which larvae live strongly affects ectothermic 386 animals. The growth of amphibians and larval development both depend on external environmental 387 factors. At higher temperatures, not only metabolic rate but also development rate increases (Motyl, 388 2008). Low temperatures reduce development rates to a greater extent than they reduce growth rate, 389 as a result of which amphibians metamorphose after achieving larger size (Wilbur \& Collins, 1973) (Ts1

390 skulls are usually larger than Ts2 skulls). Prey abundance might exert some influence as well (Motyl, 391 2008), but probably not as much (Blouin \& Loeb, 1990).

392 The Krasiejów ecosystem changed over time. The Late Triassic climate favoured evolution of freshwater 393 environments. In Krasiejów, small periodic reservoirs, probably also inhabited (as in the environments of 394 the Saar-Nahe Basin), occurred along with larger more stable ones (Szulc, 2005; 2007; Gruszka \& 395 Zieliński, 2008; Szulc, Racki \& Jewuła, 2015). Small reservoirs (and potentially with higher temperature) 396 or periodic rivers forced earlier metamorphosis, dwelling on land, or migration between lakes and 397 watercourses. On the other hand, larger lakes or the proximity of a large reservoir enabled the 398 development of a fully aquatic (Szulc, 2005), possible neotenic population.

399 Large reservoirs, stable over long periods of time, enable the development of a fully aquatic (neotenic?)

400 ecotype T1 (Tc1, Ts1), reducing the need to dwell on land by virtue of providing:

401 - enough room for numerous large specimens;

402 - shelter from mainland carnivores;

403 - stable, invariable conditions;

404 - potential lower temperatures. 
405 The ontogenetic trajectories of the two metoposaurid ecotypes from Krasiejów cannot differ on a large

406 scale, because they are assigned to the same semi-aquatic species. However, between types there was

407 clearly some deflection into a more aquatic or more terrestrial form. In the case of a more terrestrial

408 (stream-type) ecomorph, the trajectory would be more condensed (Schoch, 2001).

409

410 According to the described observations, it is possible to introduce an argument about the function of 411 temnospondyl ornamentation into the discussion. There are several hypotheses as to the function of the 412 ornamentation, which may have been:

413 1. mechanical strengthening of the bone (Coldiron, 1974; Rinehart \& Lucas, 2013);

$414 \quad 2 . \quad$ water-loss reduction (Seibert, Lillywhite \& Wassersug, 1974);

415 3. integration of the bone and skin (Romer, 1947; Bossy \& Milner, 1998);

4164 4. improvement of dermal respiration (Bystrow, 1947);

417 5. thermoregulation (Seidel, 1979; Grigg \& Seebacher, 2001);

418 6. acting as a metamorphosis marker (Boy \& Suess, 2000);

419

420

7. buffering of acidosis and lactic acid build-up in tissues due to anaerobic activity (Janis et al., 2012).

421 The microstructural observations described in this manuscript support two hypotheses. Ornamentation 422 increases the surface area of the bone (Rinehart \& Lucas, 2013) and thus improves its thermoregulatory 423 abilities and probably its integration with the skin, as histological thin sections show many Sharpey's 424 fibres residing deep in the ridges (Gądek, 2012). Moreover SEM photographs presented herein show 425 more or less numerous striations (skin and bone contact) and vascular foramina.

426 The hypothesis put forward by Janis et al. (2012) of dermal bone ornamentation developed in primitive 427 tetrapods for the purpose of buffering acidosis and lactic acid build-up in their tissues due to anaerobic 428 activity is also plausible. This would enable the amphibians to spend longer times on land and thus 429 better exploit the terrestrial environment. This statement is in agreement with a study by Witzmann et 430 al. (2010), who stated that terrestrial forms (according to species or population) show more pronounced 431 sculpture than aquatic forms.

432

433 Summary

434 The diversity of metoposaurid material from the 'Trias' site at Krasiejów (SW Poland) includes the 435 character of ornamentation of clavicles and remarks of the ornamentation of skulls (although 436 histological character suggests that all types of bones possess two types of bone growth). Similar 
437 differences in dermal bone ornamentation in Temnospondyli were cited as ecologically dependent by

438 Witzmann et al. (2010); however, these differences were assigned to particular taxa. Detailed analyses

439 of large probe from one species shows that ecologically induced ornamentation differences can be 440 observed within one species (from a single site).

441 Except for UOPB1165 specimen the taxonomical variety of the material was excluded. Observed 442 differences in polygon shape, area, sculpture density, regularity and others (Table 1, Table 6) could be 443 the result of individual, ontogenetic, sexual or ecological variation. Although some sort of sexual 444 dimorphism or ontogenetic changes cannot be excluded, the most probable explanation for the 445 described variation is ecological difference between two populations as stated by Witzmann et al. 446 (2010); or existence of facultative neotenic population. Described ornamentation types within one semi447 aquatic species possess characteristic of either more-terrestrial or more-aquatic taxa. Some ontogenetic 448 differences can be observed in both populations but they can be described separatedly in both 449 populations with the smallest (youngest) specimens having low number of ramifications and partition 450 walls within radial ornamentation and the largest (oldest) having high number of ramifications and 451 partition walls.

452 Assuming that the more-terrestrial or 'stream-type' form can be distinguished by its smaller size (earlier 453 metamorphosis), coarser and more complicated sculpture, more numerous ridges for protection of 454 more numerous blood vessels, and a stronger connection between bones and skin for increasing 455 mechanical strength for land-dwelling the more-aquatic or 'pond-type' form is characterised by greater 456 size (later metamorphosis) and sparser, more regular ornamentation. Comparable differences in 457 ontogenetic trajectories were described in Sclerocephalus by Schoch (2010).

458 This ecological diversity corresponds with the geological description of Triassic Krasiejów, which includes 459 redeposited material after flash floods, an environment with periodic rivers and ponds, and a large, 460 more stable reservoir in close proximity, as described by Szulc (2005, 2007), Gruszka \& Zieliński (2008), 461 Bodzioch \& Kowal-Linka (2012), and Szulc, Racki, \& Jewuła (2015). The palaeoenvironment of the site, 462 similar to modern Gilgai relief (Szulc, 2005; 2007; Szulc, Racki \& Jewuła, 2015) could be the habitat of 463 more terrestrial population, while the more aquatic one could have lived at some distance (closer 464 Lucas et al., 2010; or further - Konieczna, Belka \& Dopieralska, 2015). One population with aquatic 465 (paedomorphic) and terrestrial (metamorphic) individuals is also possible. In this case all metoposaurids 466 could have lived in the same area with the paedomorphic concentrating in deeper habitats (Whiteman \& 467 Semlitsch, 2005) and metamorphic being more terrestrial (moving between shallow ponds and streams).

468 Time difference between populations is also plausible. 
469 The isotopic (or REE) analysis in the future may confirm the most probable explanation for

470 metoposaurid ornamentation diversity and will provide valuable insight into the mechanism between it.

471 More information about possible ornamentation character diversity can be obtained in the future 472 considering distribution of shape (geometric morphometrics), possibly in all of the Metoposauridae.

473

\section{Acknowledgements}

475 We wish to express sincere thanks to the reviewers: Spencer Lucas, Michael Buchwitz, third anonymous 476 reviewer, and the editor Graciela Piñeiro, who kindly improved language, added many important 477 remarks and comments to an earlier versions of the typescript. We also would like to thank Tomasz Sulej 478 for sharing access to the Cyclotosaurus material from the Museum of Evolution in Warsaw and Maciej 479 Ruciński for his help in skull measurements.

480

481 
483 Literature

484 Alberch, P. 1989. Development and the evolution of amphibian metamorphosis. Fortschritte der 485 Zoologie, 35: 163-173.

486 Antczak, M. 2016. Late Triassic aetosaur (Archosauria) from Krasiejów (SW Poland): new species or an 487 example of individual variation? Geological Journal, 51: 779-788.

Antczak, M., Bodzioch, A. 2018. Diversity of fish scales in Late Triassic deposits of Krasiejów (SW Poland). Paleontological Research, 22(1): 91-100.

Babik, W., Rafiński, J. 2000. Morphometric differentiation of the moor frog (Rana arvalis Nilss.) in Central Europe. Journal of Zoological Systematics and Evolutionary Research, 38: 239-247.

Blouin, M. S., Loeb M. L. G. 1990. Effects of environmentally induced development-rate variation of the head and limb morphology in the green tree frog, Hyla cinerea. The American Naturalists, 138(3): $494717-728$.

495

496

497

498

499

500

501

502

503

504

505

506

507

508

509

510

511

512

513

514

515

Bodzioch, A., Kowal-Linka, M. 2012. Unraveling the origin of the Late Triassic multitaxic bone accumulation at Krasiejów (S Poland) by diagenetic analysis. Palaeogeography, Palaeoclimatology, Palaeoecology, 346-347: 25-36.

Bodzioch, A. 2015. Idealized model of mineral infillings in bones of fossil freshwater animals, on the example of Late Triassic metoposaurs from Krasiejów (Poland). Austin Journal of Earth Science, 2: 1-6.

Bossy, K. A., Milner, A. C. 1998. Order Nectridea Miall 1875. In: Wellnhofer, P. (eds.). Handbuch der paläoherpetologie, 1. München: Verlag Dr. Friedrich Pfeil: 73-131.

Boy, J. A. 1974. Die Larven der rhachitomen Amphibien (Amphibia: Temnospondyli; Karbon-Trias). Paläontologische Zeitschrift, 48: 236-268.

Boy, J. A. 1988. Über einige Vertrteter der Eryopoidea (Amphibia: Temnospondyli) aus dem europäischen Rotliegend (? höchstes Karbon-Perm). 1. Sclerocephalus. Paläontologische Zeitschrift, 62 : $107-132$.

Boy, J. A. 1990. Über einige Vertreter der Eryopoidea (Amphibia: Temnospondyli) aus dem europäischen Rotliegend (?höchstesKarbon - Perm). 3. Onchiodon. Paläontologische Zeitschrift, 64:287312.

Boy, J. A., Sues, H. D. 2000. Branchiosaurs: Larvae, Metamorphosis and Heterochrony in Temnospondyls and Seymouriamorphs. In: Heatwole, H., Carroll, R. L. (eds.). Amphibian Biology 4. Palaeontology, Chipping Norton: Surrey Beatty: 1150-1197.

Brusatte, S. L., Butler, R. J., Sulej, T., Niedźwiecki, G. 2009. The taxonomy and anatomy of rauisuchian from the Late Triassic of Germany and Poland. Acta Palaeontologica Polonica, 54(2): 221230. 
516 Brusatte S. L, Butler R. J., Mateus O., Steyer J. S. 2015. A new species of Metoposaurus from the

517 Late Triassic of Portugal and comments on the systematics and biogeography of metoposaurid

518 temnospondyls. Journal of Vertebrate Paleontology, DOI: 10.1080/02724634.2014.912988.

519 Bystrow, A. P. 1947. Hydrophilous and xerophilous labyrinthodonts. Acta Zoologica (Stockholm), 28:

$520 \quad 137190-274164$.

521 Coldiron, R. W. 1974. Possible functions of ornament in labyrinthodont amphibians. Occasional Papers

522 of the Museum of Natural History of Lawrence, 33: 1-19.

523 Collins, J. P., Cheek, J. E. 1983. Effect of food and density on development of typical and cannibalistic

524 salamander larvae in Ambystoma tigrinum nebulosum. American Zoologist, 23: 77-84.

525 Davidow-Henry, B. R. 1989. Small metoposaurid amphibians from the Triassic of western North

526 America and their significance. In: Lucas, S. G., Hunt, A. P. (eds.). Dawn of the age of dinosaurs in the

527 American southwest: 278-292. New Mexico Museum of Natural History, Albuquerque.

528 Dubois, A., 1982. Notes sur les grenouilles brunes (groupe de Ranatemporaria) I. Introduction. Alytes, 1:

$52956-70$.

530 Duellman, W., Trueb, L. 1986. Biology of Amphibians. Mc Graw-Hill Book Comp. New York, St.

531 Louis, San Francisco, pp. 1-670.

532 Dzik, J., Sulej, T. 2007. A review of the early Late Triassic Krasiejów biota from Silesia, Poland.

533 Palaeontologia Polonica, 64: 3-27.

534 Dzik, J., Sulej, T. 2016. An early Late Triassic long-necked reptile with a bony pectoral shield and

535 gracile appendages. Acta Palaeontologica Polonica, 61(4), DOI: 10.4202/app.00276.2016.

536 Emerson, S. B. 1986. Heterochrony and frogs: the relationship of a life history trait to morphological

537 form. American Naturalist, 127: 67-183.

538 Emerson, S. B., Travis, J., Blouin, M. 1988. Evaluating a hypothesis about heterochrony: larval life

539 history traits and juvenile hind-limb morphology in Hyla crucifer. Evolution, 42: 68-78.

540 Fortuny, J., Marcé-Nogué, J., Konietzko-Meier, D. 2017. Feeding biomechanics of Late Triassic 541 metoposaurids (Amphibia: Temnospondyli): a 3D finite analysis approach. Journal of anatomy, DOI: $54210.1111 /$ joa.12605

543 Fritzsch, B. 1990. The evolution of metamorphosis in amphibians. Journal of Neurobiology, 21: 10115441021.

545 Frobisch, N. B., Schoch, R. R. 2009. The largest specimen of Apateon and the life history path way of neoteny in the Paleozoic temnospondyl family Branchiosauridae. Fossil Record, 12(1): 83-90.

547 Gądek, K. 2012. Palaeohistology of ribs and clavicle of Metoposaurus diagnosticus from Krasiejów

548 (Upper Silesia, Poland). Opole Scientific Society Natural Journal, 45: 39-42. 
549 Ghioca-Robrecht, D. M., Smith, L. M., Densmore, L. D. 2009. Ecological correlates of trophic

550 polyphenism in spadefoot tadpoles inhabiting playas. Canadian Journal of Zoology, 87: 229-238.

551 Grigg, G., Seebacher, F. 2001. Crocodilian thermal relations. In: Grigg, G. C., Seebacher, F., Franklin, 552 C.E., (eds.). Crocodilian biology and evolution, Chipping Norton: Surrey Beatty: 297-309.

553 Gruntmejer, K., Konietzko-Meier, D., Bodzioch, A. 2016. Cranial bone histology of Metoposaurus

554 krasiejowensis (Amphibia, Temnospondyli) from the Late Triassic of Poland. PeerJ, 4:e2685; DOI:

555 10.7717/peerj.2685.

556 Gruszka, B., Zieliński, T.2008. Evidence for a very low-energy fluvial system: a case study from the

557 dinosaur-bearing Upper Triassic rocks of Southern Poland. Geological Quarterly, 52: 139-252.

558 Janis, C.M., Devlin, K., Warren, D.E. and Witzmann, F., 2012. Dermal bone in early tetrapods: A 559 paleophysiological hypothesis of adaptation for terrestrial acidosis. Proceedings of the Royal Society B 560 Biological Sciences, 279: 3035-3040.

561 Konieczna, N., Belka, Z., Dopieralska, J., 2015. Nd and Sr isotopic evidence for provenance of clastic

562 material of the Upper Triassic rocks of Silesia, Poland. Annales Societatis Geologorum Poloniae, 85 :

$563675-684$.

564 Konietzko-Meier, D., Klein, N. 2013.Unique growth pattern of Metoposaurus diagnosticus

565 krasiejowensis (Amphibia, Temnospondyli) from the Upper Triassic of Krasiejów, Poland.

566 Palaeogeography, Palaeoclimatology, Palaeoecology, 370: 145-157.

567 Konietzko-Meier, D., Sander, P. M. 2013. Long bone histology of Metoposaurus diagnosticus

568 (Temnospondyli) from the Late Triassic of Krasiejów (Poland) and its palaeobiological implicatios.

569 Journal of Palaeontology, 33: 1003-1018.

570 Konietzko-Meier, D, Gruntmejer, K., Marcé-Nogué, J., Bodzioch, A., Fortuny, J. 2018. Merging

571 cranial histology and 3D-computational biomechanics: a review of the feeding ecology of a Late Triassic

572 temnospondyl amphibian. PeerJ, 6:e4426; DOI: 10.7717/peerj.4426

573

574

Krenz, J. D, Sever, D. M. 1995. Mating and oviposition in paedomorphic Ambystoma talpoideum

575 precedes the arrival of terrestrial males. Journal of Herpetology, 51: 387-393.

Kupfer, A. 2007. Sexual size dimorphism in amphibians: an overview. Chapter 5. In: Fairbairn, D. J.,

577 Blanckenhorn, In. U., Szekely, T. (eds.). Sex, size and gender roles: evolutionary studies of sexual size dimorphism,, Oxford University Press:50-59.

579

580

Lucas, S. G. 2015. Age and correlation of Late Triassic tetrapods from southern Poland. Annales

581 Societatis Geologorum Poloniae, 85: 627-635.

582

583

Lucas, S. G., Rinehart, L. F., Krainer, K., Spielmann, A., Heckert, A. B. 2010. Taphonomy of the Lay 584

585 amphibian quarry: A Late Triassic bonebed in New Mexico, USA. Palaeogeography, Palaeoecology, Palaeoclimatology, 298: 388-398. 
586

587

588

589

590

591

592

593

594

595

596

597

598

599

600

601

602

603

604

605

606

607

608

609

610

611

612

613

614

615

618

616 Roff, D. E. 1996. The evolution of threshold traits in animals. Quarterly Review of Biology, 71: 3-35

617 Romer, A. S. 1947. Review of the Labyrinthodontia. Bulletin of the Museum of Comparative Zoology at

Lucas, S. G., Rinehart, L. F., Heckert, A. B., Hunt, A. P., Spielmann, J. 2016. Rotten Hill: a Late Triassic bone-bed in the Texas Panhandle, USA. New Mexico Museum of Natural History and Science Bulletin, 72: 1-97.

Michimae, H., Wakahara, M. 2002. A tadpole-induced polyphenism in the salamander Hynobius retardatus. Evolution, 56: 2029-2038.

Motyl, M. 2008. Od czego zależy metamorfoza [What determines the metamorphosis]. [amphibia.org.pl].

Norris, D. 1999. Thyroid hormones, in subavian vertebrates. In: Knobil, E., Neill J. D. (eds.).

Encyclopedia of Reproduction ., 4, Academic Press, New York: 807-812.

Nyman, S., Wilinson, R. F., Hutcherson, J. E. 1993. Cannibalism and size relations in a cohort of larval ringed salamanders (Ambystoma annulatum). Journal of Herpetology, 27: 78-84.

Piechowski, R., Dzik, J. 2010. The axial skeleton of Silesaurus opolensis. Journal of Vertebrate Palaeontology, 30: 1127-1141.

Pfennig, D.W. 1990. The adaptive significance of an environmentally-cued developmental switch in an anuran tadpole. Oecologia, 85: 101-107.

Pfennig, D. W. 1992. Polyphenism in spadefoot toad tadpoles as a locally-adjusted evolutionarily stable strategy. Evolution, 46: 1408-1420.

Pfennig, D. W., McGee, M. 2010. Resource polyphenism increases species richness: a test of the hypothesis. Philosophical Transactions of the Royal Society B, 365: 577-591.

Pogodziński, D., Hermaniuk, A., Stępniak, K. 2015. Phenotypic variability of the moor frog (Rana arvalis) in populations from Podlasie and Wielkopolska. IVth Student Herpetological Conference, Abstractbook: 1-2.

Rafiński, J., Babik, W. 2000. Genetic differentiation among northern and southern populations of the moor frog Rana arvalis Nilsson in Central Europe. Heredity, 84: 610-618.

Rinehart, L. F., Lucas, S. G., Heckert, A. B., Hunt, A. P. 2008. Preliminary analysis of growth and age structure of Buettneria (Amphibia: Metoposauridae) assemblages from the Upper Triassic of West Texas and New Mexico. New Mexico Geology, 30: 56.

Rinehart, L. F., Lucas, G. L. 2013. The functional morphology of dermal bone ornamentation in temnospondyl amphibians. In: Tanner, L.H., Spielmann, J.A., Lucas, S.G. (eds.). The Triassic System. New Mexico Museum of Natural History and Science, Bulletin, 61. Harvard, 99: 1-368. 
619 Safi, R., Bertrands, S., Marchand, O., Duffraisse, M., Luze, A., Vanacker, J., Maraninchi, M., 620 Margotat, A., Demeneix, B., Laudet, V. 2004. The axolotl (Ambystoma mexicanum), a neotenic 621 amphibian, express functional thyroid hormone receptors. Endochrynology, 154: 760-722.

622 Sanchez, S., Schoch, R. R. 2013. Bone histology reveals a high environmental and metabolic plasticity 623 as a successful evolutionary strategy in a long-lived homeostatic Triassic temnospondyl. Evolutionary 624 Biology, DOI: 10.1007/s11692-013-9238-3.

625 Schmidt, K. P. 1938. A geographic variation gradient in frogs. Field Museum of Natural History. 626 Zoological series, Chicago 20: 377-382.

627 Schoch, R. R. 1995. Heterochrony in the evolution of the amphibian head. In: McNamara K. (ed.). 628 Evolutionary change and heterochrony, Wiley, Chichester, U.K.: 107-124.

629 Schoch, R. R. 2001. Can metamorphosis be recognized in Paleozoic amphibians? Neues Jahrbuch für 630 Geologie und Paläontologie Abhandlungen, 220(3): 335-367.

631 Schoch, R. R. 2002. The evolution of metamorphosis in temnospondyls. Lethaia, 35: 309-327.

632 Schoch, R. R. 2004. Skeleton formation in the Branchiosauridae: a case study in comparing ontogenetic 633 trajectories. Journal of Vertebrate Paleontology, 24: 309-319.

634 Schoch, R. R. 2009. Life-cycle evolution as response to diverse lake habitats in Paleozoic amphibians. 635 Evolution, 63: 2738-2749.

636 Schoch, R. R. 2010. Heterochrony: the interplay between development and ecology exemplified by a 637 Paleozoic amphibian clade. Paleobiology, 36(2): 318-334

638 Schoch, R. R., Witzmann, F. 2012. Cranial morphology of the plagiosaurid Gerrothorax pulcherrimus 639 as an extreme example of evolutionary stasis. Lethaia, 45: 371-385.

640 Seidel, M. R. 1979. The osteoderms of the American Alligator and their functional significance. 641 Herpetologica, 35: 375-380.

642

Seibert, E. A., Lillywhite, H. B., Wassersug, R. J. 1974. Cranial co-ossification in frogs: relationship to 644

645

646

Skrzycki, P. 2015. New species of lungfish (Sarcopterygii, Dipnoi) from the Late Triassic Krasiejów site 647 in Poland, with remarks on the ontogeny of Triassic dipnoan tooth plates. Journal of Vertebrate

648 Palaeontology, 35(5), DOI: 10.1080/02724634.2015.964357.

649 Sulej, T. 2002. Species discrimination of the Late Triassic temnospondyli amphibian Metoposaurus 650 diagnosticus. Acta Palaeontologica Polonica, 47: 535-546.

651 Sulej, T. 2007. Osteology, variability, and evolution of Metoposaurus, a temnospondyl from the Late 652 Triassic of Poland. Palaeontologia Polonica, 64: 29-139. 
653 Sulej, T. 2010. The skull of an early Late Triassic aetosaur and the evolution of the stagonolepidid 654 archosaurian reptiles. Zoological Journal of the Linnean Society, 158(4): 860-881.

655 Sulej, T., Majer, D. 2005. The temnospondyl amphibian Cyclotosaurus from the Upper Triassic of 656 Poland. Palaeontology, 48(1): 157-170.

657 Szulc, J. 2005. Sedimentary environments of the vertebrate-bearing Norian deposits from Krasiejów, 658 Upper Silesia (Poland). Hallesches Jahrbuch für geowissenschaften Reihe B, 19: 161-170.

659 Szulc, J. 2007. Stop I.4. Krasiejów—inactive clay pit and tetrapod exposition. In: Szulc, J., Becker, A. 660 (eds.). International Workshop on the Triassic of Southern Poland. Polish Geological Institute and 661 Institute of Geological Sciences, Jagiellonian University,Cracow: 53-55.

662 Szulc, J., Racki, G., Jewuła, K. 2015. Key aspects of the stratigraphy of the Upper Silesian middle 663 Keuper, southern Poland. Annales Societatis Geologorum Poloniae, 85: 557-586.

664 Teschner E. M., Sander, P., Konietzko-Meier, D. 2017. Variability of growth pattern observed in 665 Metoposaurus krasiejowensis humeri and its biological meaning. Journal of Iberian Geology, DOI: $66610.1007 / \mathrm{s} 41513-017-0038-\mathrm{y}$.

667 Urban, D. S., Berman, M. 2007. First occurrence of the Late Paleozoic amphibian Zatrachys serratus 668 (Temnospondyli, Zatrachydidae) in the eastern United States. Annals of Carnegie Museum, 76: 157-164.

669 Walls, S. C., Belanger, S. S., Blaustein, A. R. 1993. Morphological variation in a larval salamander: 670 dietary induction of plasticity in head shape. Oecologia, 96: 162-168.

671 Werneburg, R., 1991. Die Branchiosaurier aus dem Unterrotliegend des Döhlener Beckens bei Dresden.

672 Veröff. Naturhistorisches Museum Schloss Bertholdsburg Schleusingen, 6: 75-99.

673 Werneburg, R., 2002. Apateon dracyiensis - eine frühe pionierform der Branchiosaurier aus dem 674 Europäischen Rotliegend, Teil 2: Paläoökologie. Veröff. Naturhistorisches Museum Schloss

675 Bertholdsburg Schleusingen, 17: 17-32.

676 Werneburg, R., Ronchi, A., Schneider, J. W. 2007. The Early Permian branchiosaurids (Amphibia) of 677 Sardinia (Italy): systematic palaeontology, palaeoecology, biostratigraphy and palaeobiogeographic 678 problems. Palaeogeography, Palaeoclimatology, Palaeoecology, 252: 383-404.

679 Wilbur, H. M., Collins, J. P. 1973. Ecological Aspects of Amphibian Metamorphosis: Nonnormal 680 distributions of competitive ability reflect selection for facultative metamorphosis. Science, 182(4119): $6811305-1314$.

682 Witzmann, F., Henning, S., Muller, J., Kardjilov N. 2010. Sculpture and vascularization of dermal 683 bones, and the implications for the physiology of basal tetrapods. Zoological Journal of Linnean Society, 684 160: $302-340$.

685 Whiteman, H. H. 1994. Evolution of facultative paedomorphosis in salamanders. Quarterly Review of 686 Biology, 69: 205-221. 
687 Whiteman, H. H., Krenz, J. D., Semlitsch, R. D. 2005. Intermorph breeding and the potential for

688 reproductive isolation in polymorphic mole salamanders (Ambystoma talpoideum). Behavioral Ecology

689 and Sociobiology, DOI:10.1007/s00265-005-0139-z.

690 Whiteman, H. H., Semlitsch, R. D. 2005. Asymmetric reproductive isolation among polymorphic

691 salamanders. Biological Journal of the Linnean Society, 86: 265-28.

692 Zalecka K. 2012. Międzyobojczyk Metoposaurus diagnosticus krasiejowensis (Amphibia,

693 Temnospondyli) ze stanowiska dokumentacyjnego 'Trias' w Krasiejowie. [Interclavicle of Metoposaurus

694 diagnosticus krasiejowensis (Amphibia, Temnospondyli) from 'Trias' site in Krasiejów. Unpublished

695 Master Thesis. Opole University: 1-81.

696 Zug, G. R. 1993. Herpetology. An introductory biology of amphibians and reptiles. Academic Press

697 Limited, London. ISBN 0-12-782620-3: 1 -527.

698

699 Figure captions

700 Figure 1: Localization and geological map of Krasiejów (after Bodzioch \& Kowal-Linka, 2012).

701

702 Figure 2: Clavicles ornamentation character.

703 (A) Basic ornamentation features explanation. (B) Clavicle assigned to ornamentation type 2

704 (Tc2). (C) Clavicle assigned to ornamentation type 1 (Tc1). (D) UOBP1165, partially incomplete

705 specimen, not fitting to the described types (C, Figs. 4-6).

706

707 Figure 3: Thickness of the bone in particular types and ontogenetic stages.

708 Measurements made at the border of polygonal and radial ornamentation areas.

709

710 Figure 4: Ratio of the bone width and amount of radial ridges.

711 Measurement taken $2.5 \mathrm{~cm}$, from ossification centre.

712 (A) Considering appointed types, showing two subsets within metoposaurid data. (B)

713 Considering individual age, showing no subsets within metoposaurid data.

714

715

716 Figure 5: Ratio of polygon number and surface.

717 (A) Considering appointed types, showing two subsets within metoposaurid data. (B)

718 Considering individual age, showing no subsets within metoposaurid data.

719

720

Figure 6: Ratio of multipolygon and all polygon numbers.

721

(A) Considering appointed types, showing two subsets within metoposaurid data. (B)

722

Considering individual age, showing no subsets within metoposaurid data.

723

724 Figure 7: Percentage of hexagonal, pentagonal and other polygons. 
725 (A) Considering appointed types, showing two subsets within metoposaurid data. (B)

726 Considering individual age, showing no subsets within metoposaurid data.

727

728 Figure 8: SEM (SE) and histological observations of clavicle radial ridges for Tc1.

729 (A-B) UOPB1152. (C-D) UOPB1161. (E) UOPB1160. (F) UOPB1167. (G) UOPB1170.

730

731 Figure 9: SEM (SE) and histological observations of clavicle radial ridges for Tc2.

732 (A-B) uam/kng/02. (C-D) UOBP1157. (E-F) UOPB1163. (G) UOPB1172. (H) UOPB1158. (I)

733 UOPB1163.

734

735 Figure 10: Types of skulls ornamentation of metoposaurids from Krasiejów (M. krasiejowensis,

736 as explained at Fig. 11). Blue area represents surface covered with radial ornamentation. (A)

737 UO/PP20. (B) UO/PP13. (C) UO/PP08. (D) UO/PP09. (E) Ts2 skull. (F) Ts1 skull. Scale bar 5

$738 \mathrm{~cm}$.

739

740 Figure 11: Comparison of analyzed skull material (examples) with reconstructions of 741 Metoposaurus diagnosticus, M. krasiejowensis and M. algavrensis skulls.

742 (A) M. algavrensis. (B) M. krasiejowensis. (C) M. algavrensis. (D) $\mathrm{UO} / \mathrm{PP} 02$ (Ts2). (E) 743 UO/PP09 (Ts1). (F) UO/PP13 (Ts1). (G) UO/PP04 (Ts1). A-C after Brusatte et al., 2015.

744

745

Figure 12: Skull measurements.

746

747 Figure 13: Ontogenetic stages in clavicles. Arrows show partition walls and ramifications within 748 radial ridges.

749 (A-C) Ornamentation type 2 (Tc2) from possibly the youngest specimen to the oldest one. (D-F) 750 Ornamentation type 1 ( $\mathrm{Tc} 1)$ from possibly the youngest specimen to the oldest one. (A) 751 UOPB1155. (B) UOPB1168. (C)UOPB1164. (D)UOPB1171. (E) UOPB1166. (F)UOPB1152. 752 


\section{Tables}

755

756

757 Types numerical codes:

758

759

760 Metoposaurus 1(aquatic, pond-type): 111211311111111112111 ?

761 Metoposaurus 2(terrestrial, stream-type): 2221322212222222122

762

763

764

765

766

767

768 
Figure 1

Localization and geological map of Krasiejów (after Bodzioch \& Kowal-Linka, 2012).
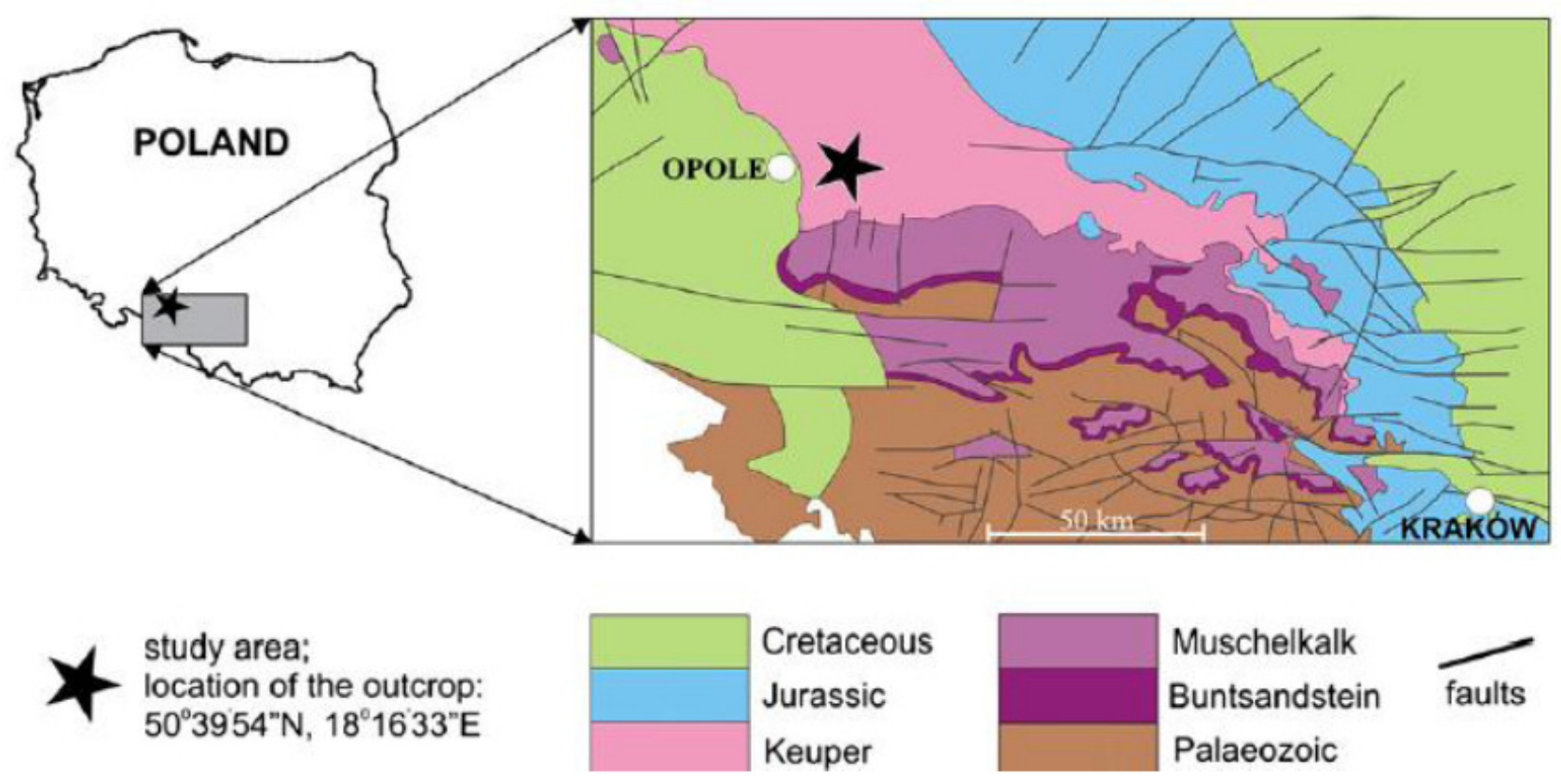


\section{Figure 2}

Clavicles ornamentation character.

(A) Basic ornamentation features explanation. (B) Clavicle assigned to ornamentation type 2

(TC2). (C) Clavicle assigned to ornamentation type 1 (Tc1). (D) UOBP1165, partially incomplete specimen, not fitting to the described types (C, Figs. 4-6).
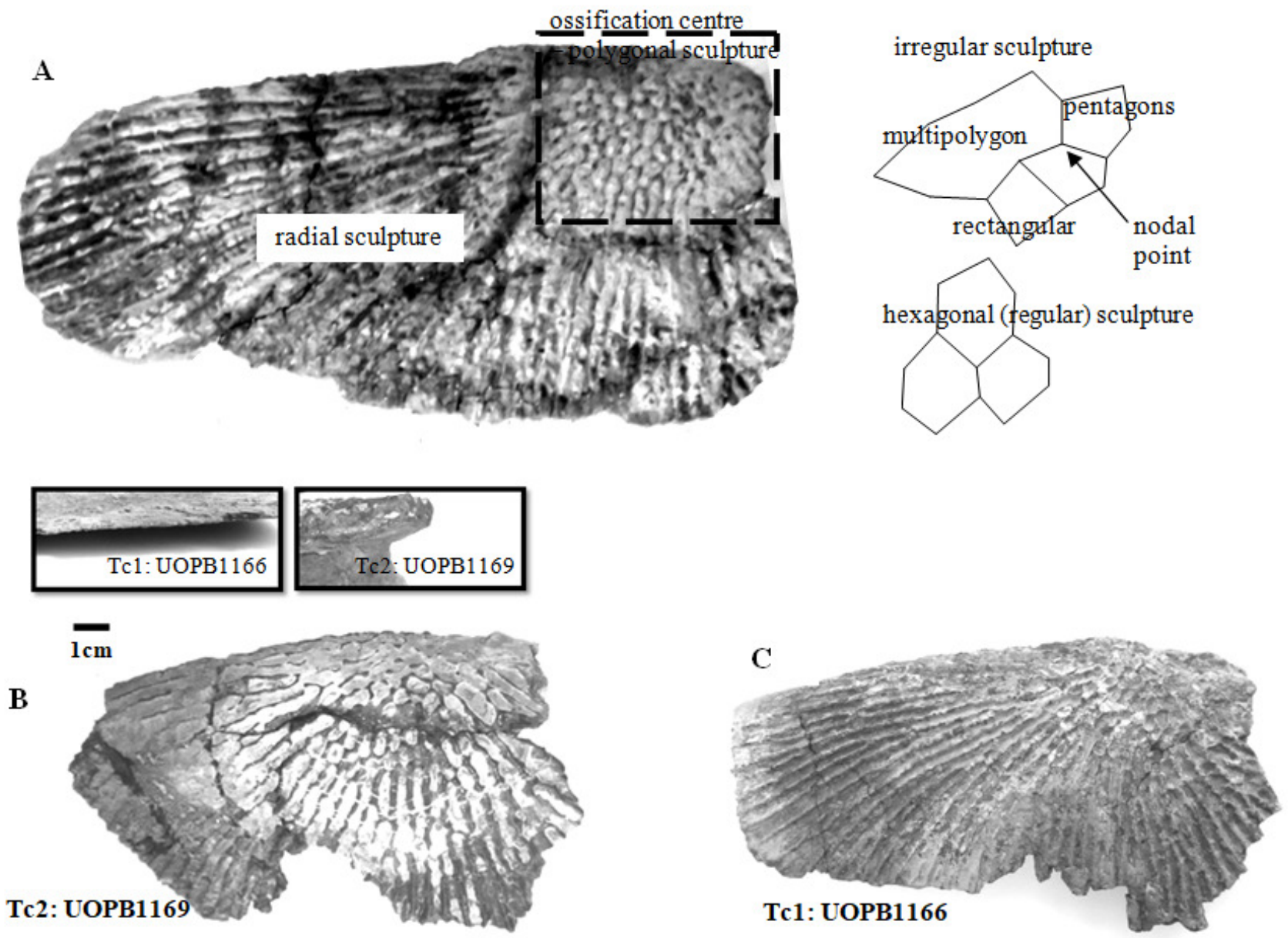

D

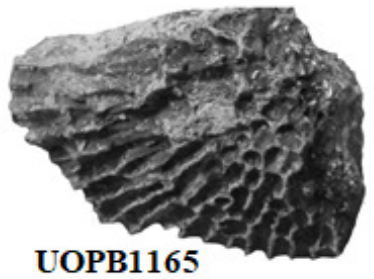


Figure 3

Thickness of the bone in particular types and ontogenetic stages.

Measurements made at the border of polygonal and radial ornamentation areas.

- Tc1

$\rightarrow \mathrm{Tc} 2$

Youngest

Intermediate

$\triangle$ Oldest

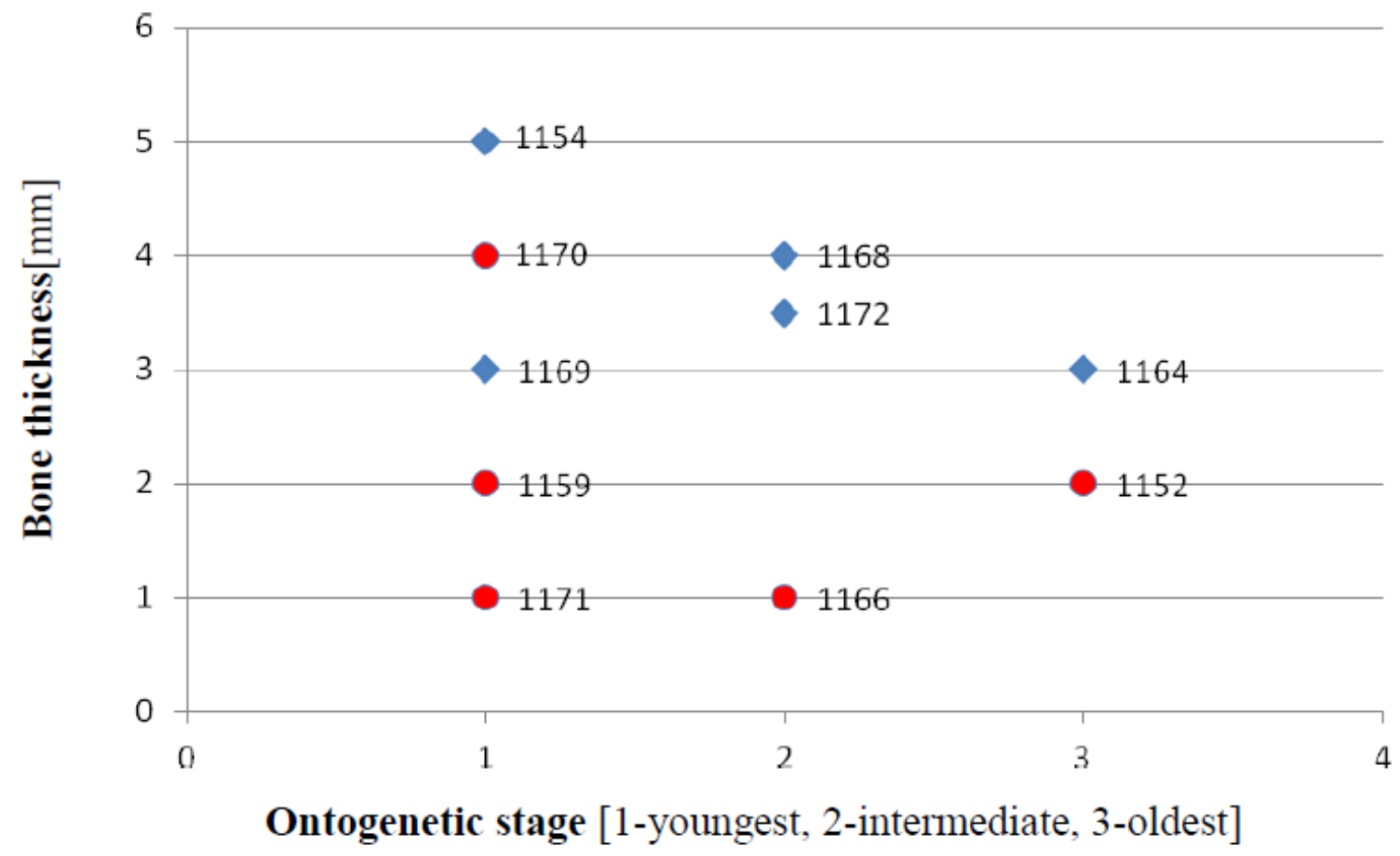




\section{Figure 4}

Ratio of the bone width and amount of radial ridges.

Measurement taken $2.5 \mathrm{~cm}$, from ossification centre. (A) Considering appointed types, showing two subsets within metoposaurid data. (B) Considering individual age, showing no subsets within metoposaurid data. 
- Tc1 Youngest

$-\mathrm{Tc} 2 \bullet$ Intermediate

$\triangle$ Oldest
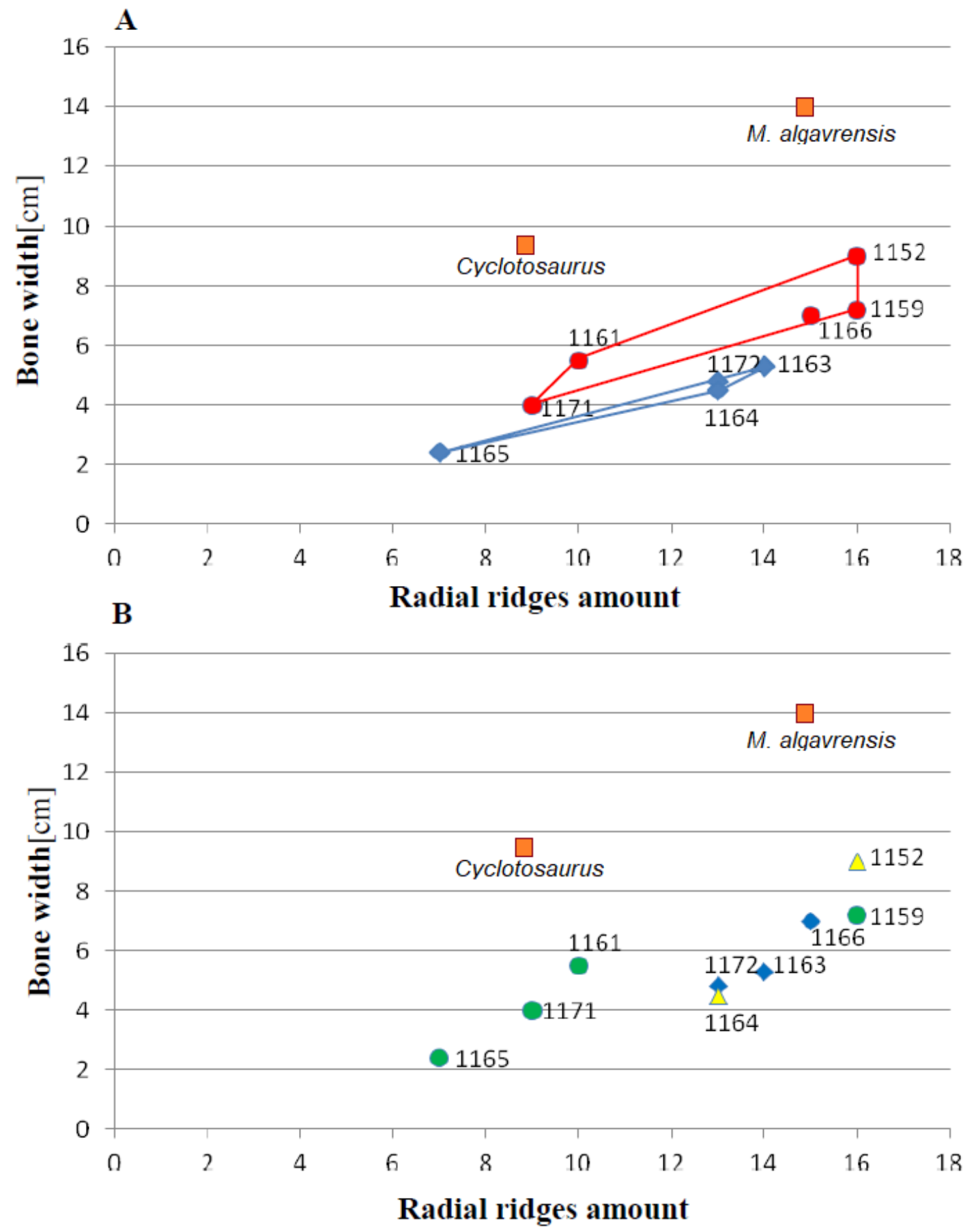
Figure 5

Ratio of polygon number and surface.

(A) Considering appointed types, showing two subsets within metoposaurid data. (B) Considering individual age, showing no subsets within metoposaurid data. 
- Tc1 Youngest

$-\mathrm{Tc} 2 \bullet$ Intermediate

$\triangle$ Oldest
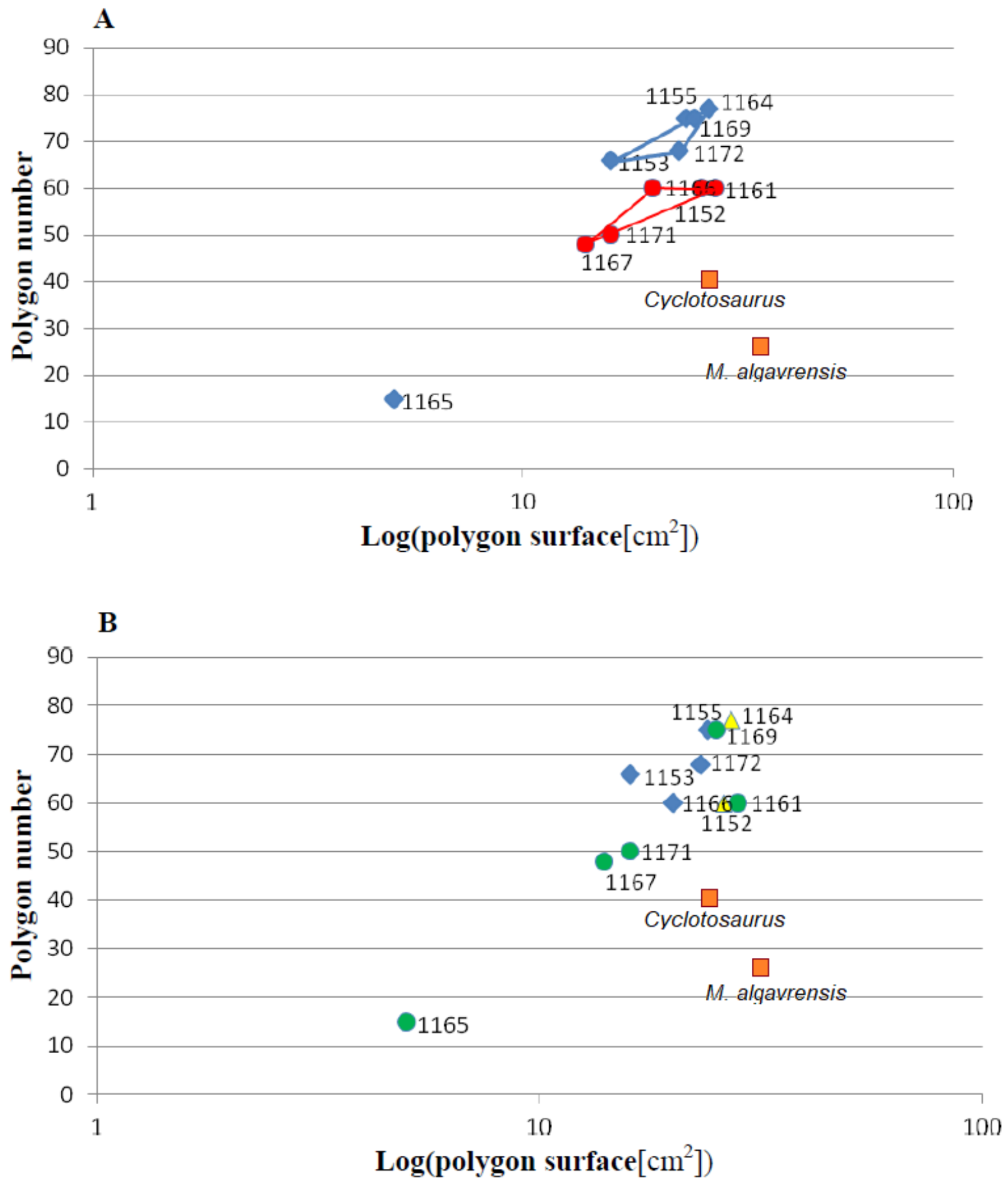


\section{Figure 6}

Ratio of multipolygon and all polygon numbers.

(A) Considering appointed types, showing two subsets within metoposaurid data. (B) Considering individual age, showing no subsets within metoposaurid data. 
- Tc1 Youngest

Tc2 Intermediate

Oldest

A

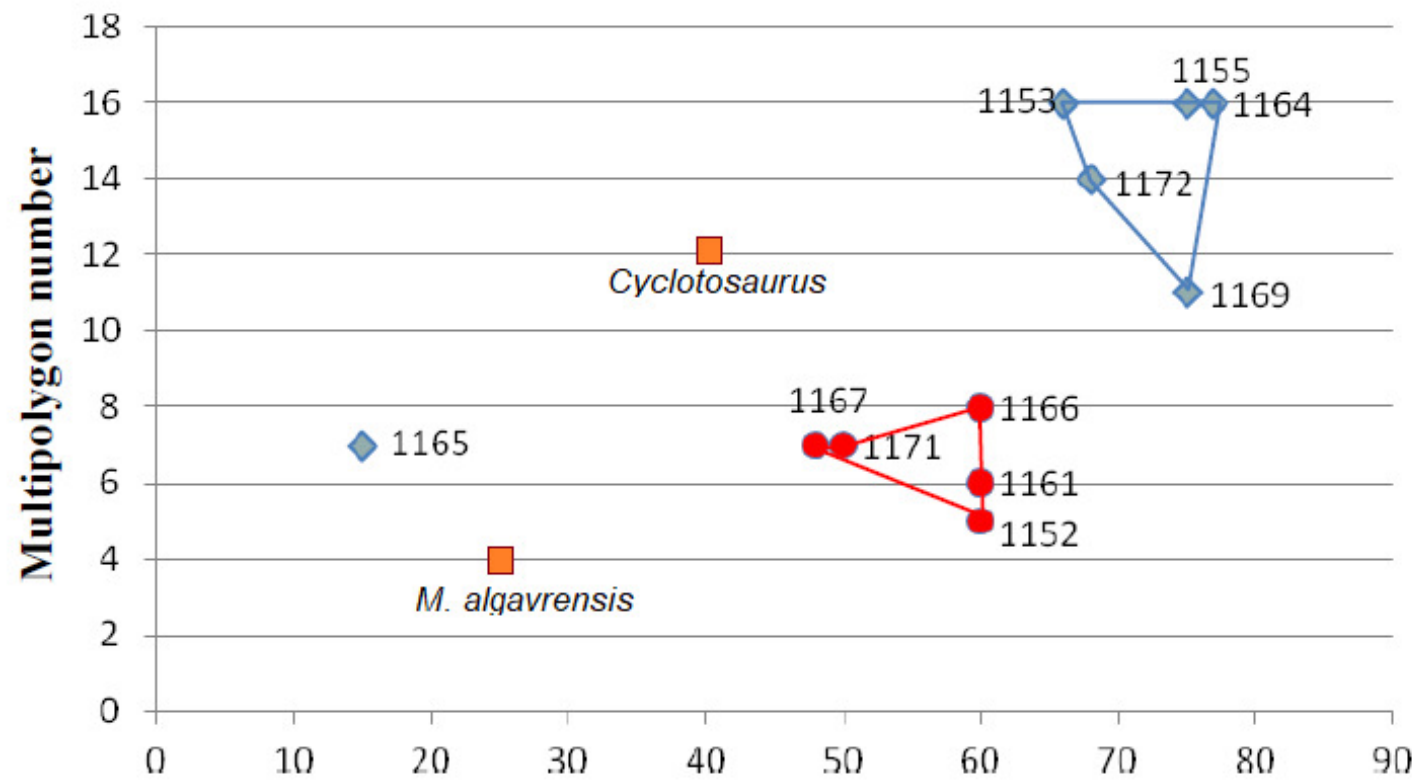

Polygon number

B

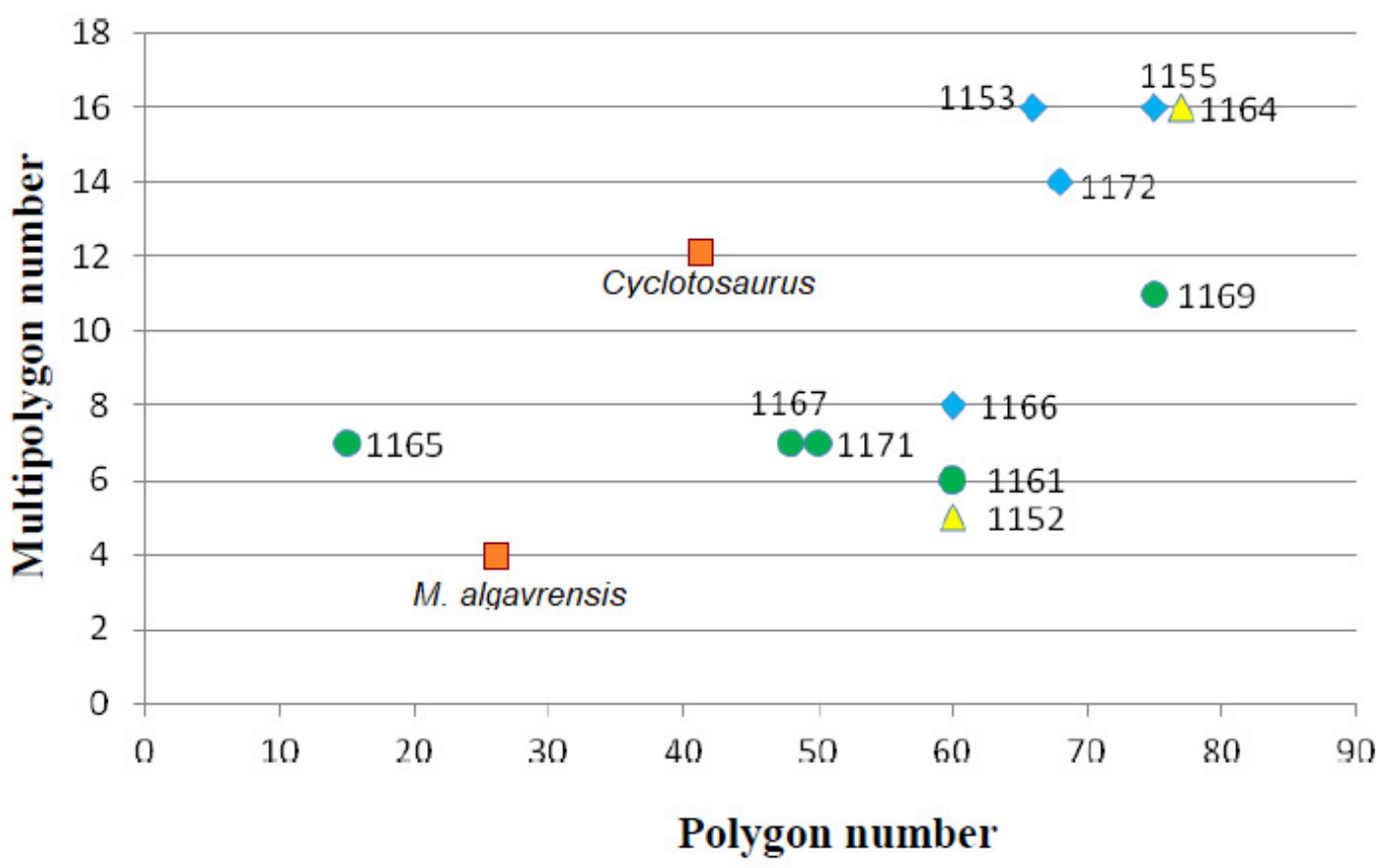


Figure 7

Percentage of hexagonal, pentagonal and other polygons.

(A) Considering appointed types, showing two subsets within metoposaurid data. (B) Considering individual age, showing no subsets within metoposaurid data. 

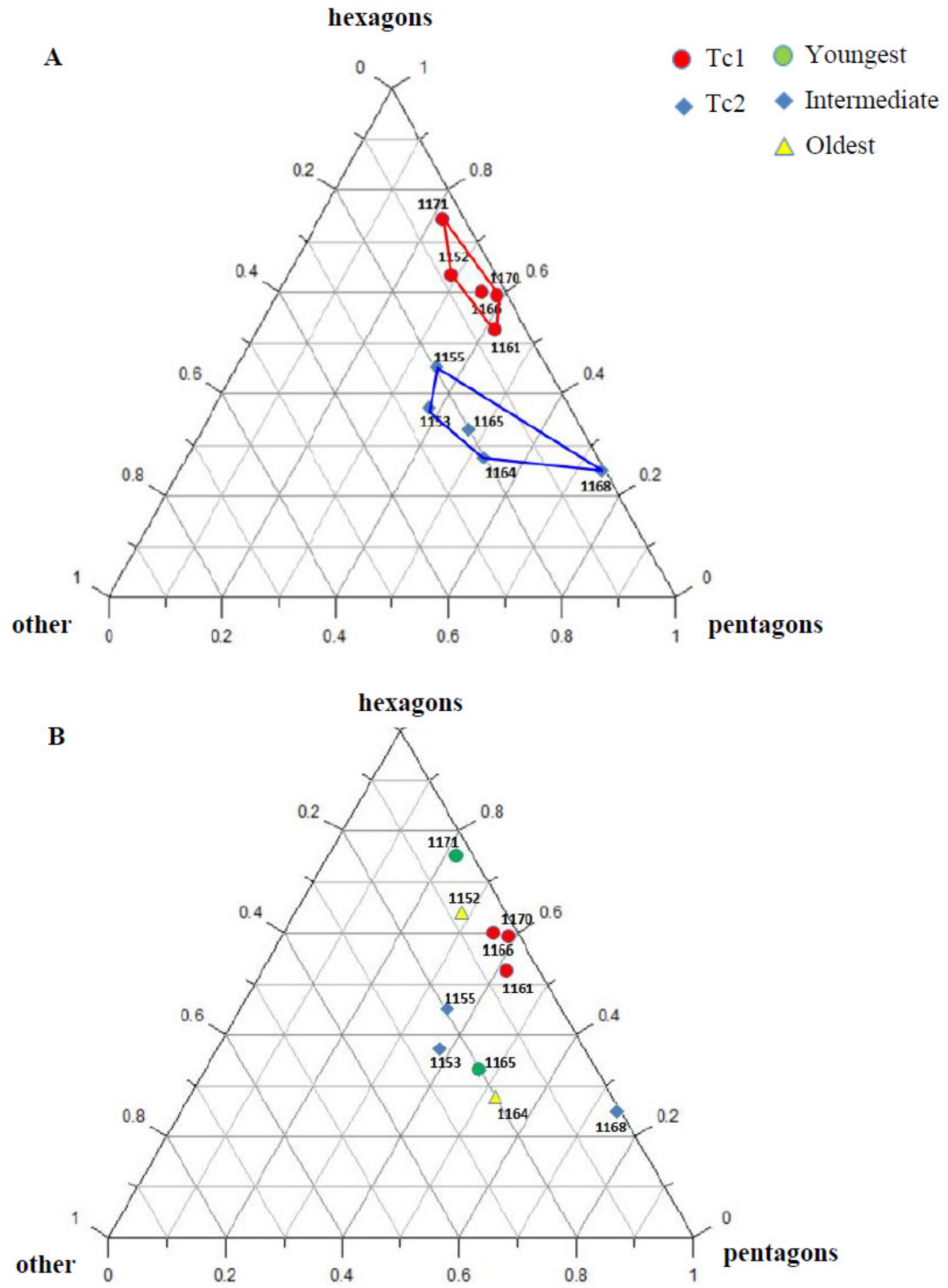
Figure 8

SEM (SE) and histological observations of clavicle radial ridges for Tc1.

(A-B) UOPB1152. (C-D) UOPB1161. (E) UOPB1160. (F) UOPB1167. (G) UOPB1170. 


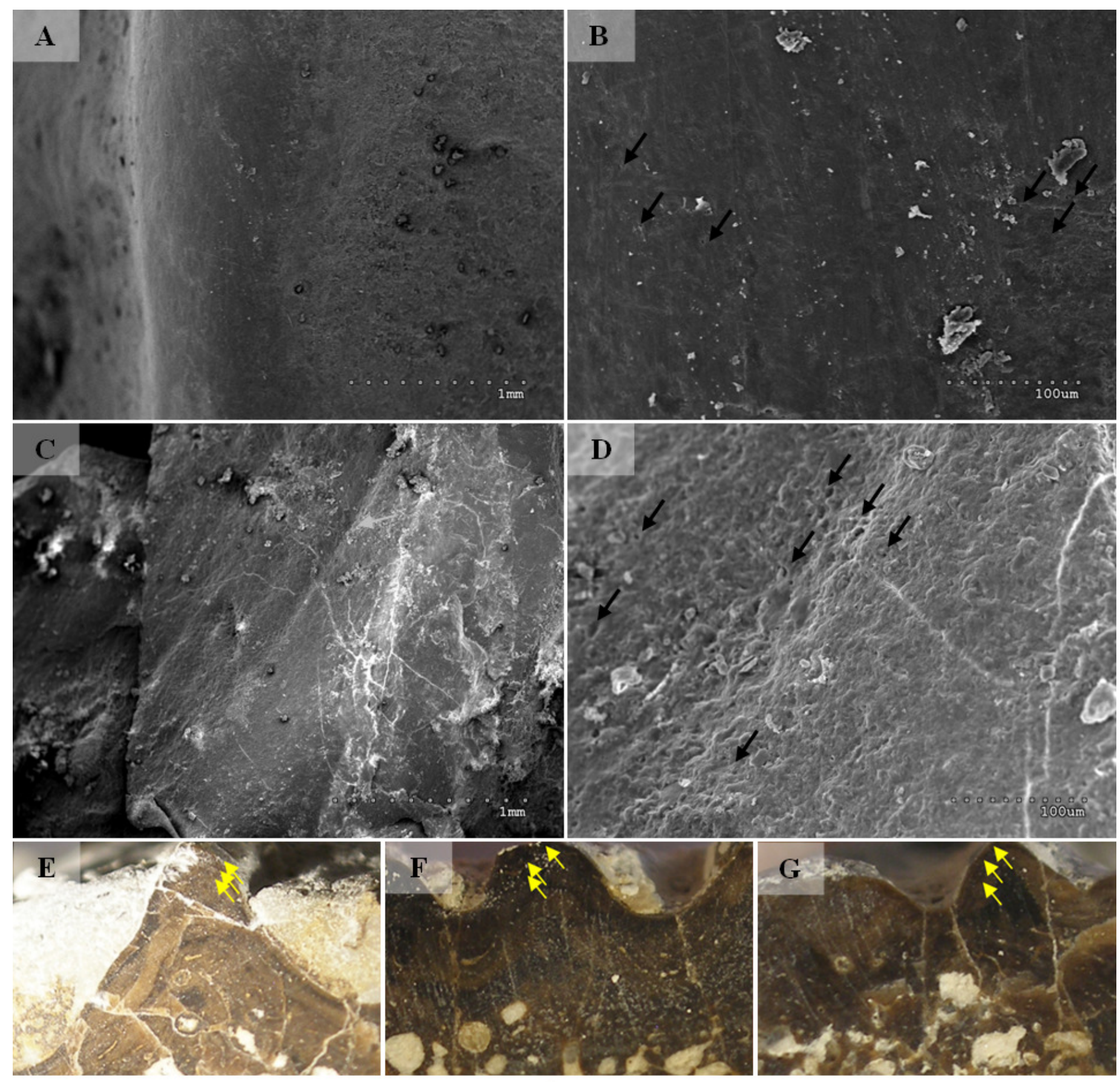

sharp edge foramen $\downarrow$

striations and bumps

growth marks

zones (vascularised bone) 
Figure 9

SEM (SE) and histological observations of clavicle radial ridges for Tc2.

(A-B) uam/kng/02. (C-D) UOBP1157. (E-F) UOPB1163. (G) UOPB1172. (H) UOPB1158. (I) UOPB1163. 


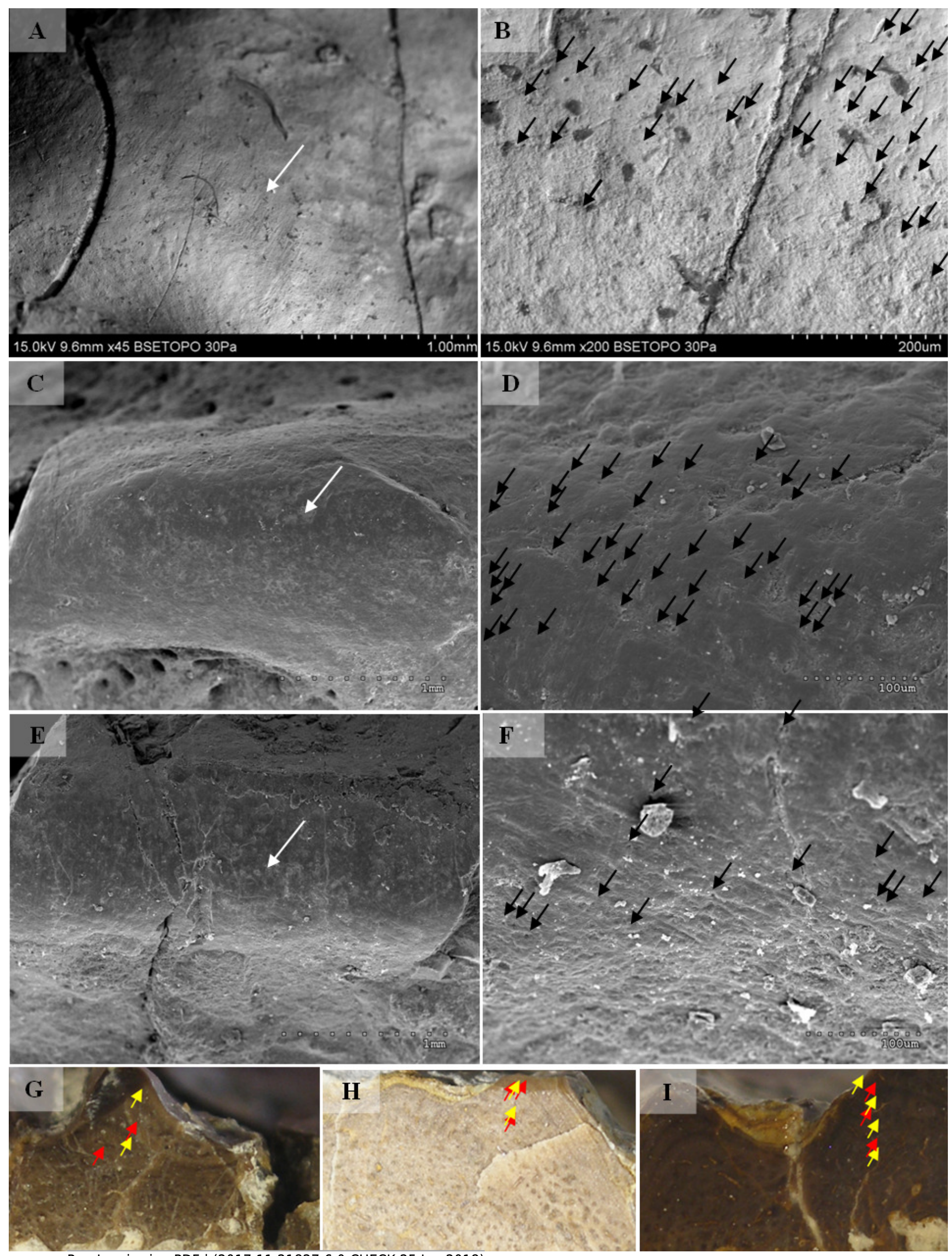




\section{Figure 10}

Types of skulls ornamentation of metoposaurids from Krasiejów (M. krasiejowensis, as explained at Fig. 11).

Blue area represents surface covered with radial ornamentation. (A) UO/PP20. (B) UO/PP13. (C) UO/PP08. (D) UO/PP09. (E) Ts2 skull. (F) Ts1 skull. Scale bar $5 \mathrm{~cm}$.
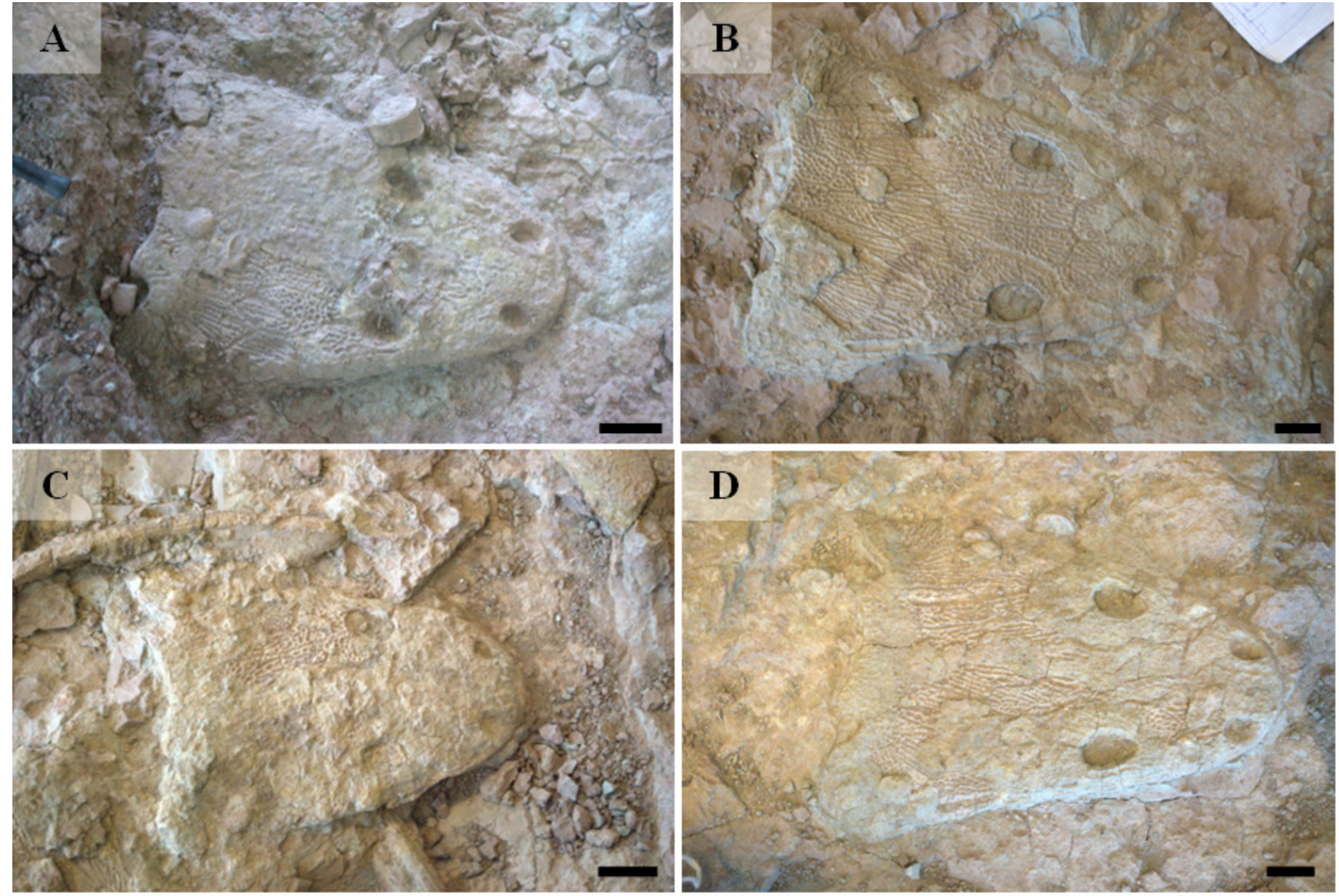

$\mathbf{E}$

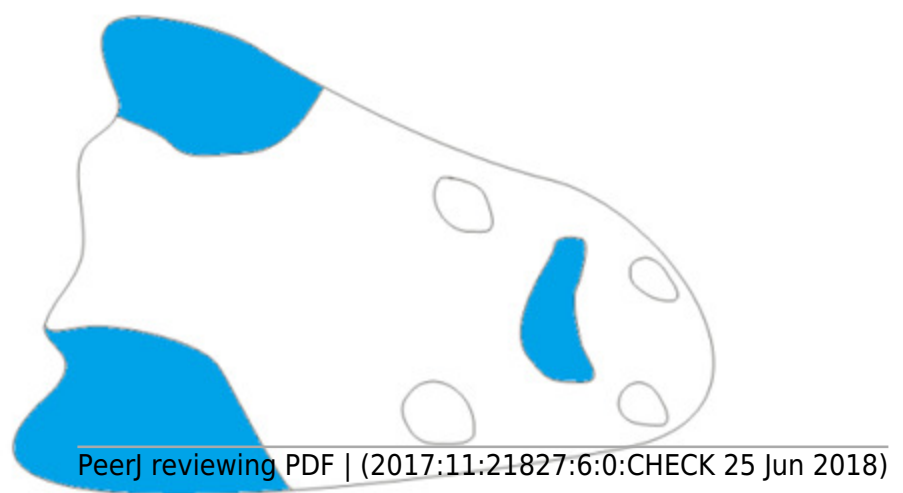

$\mathbf{F}$

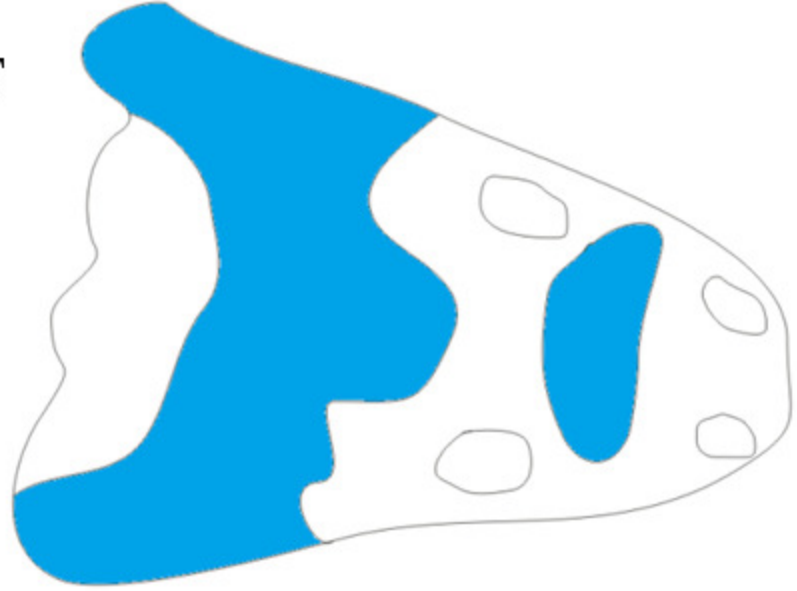




\section{Figure 11}

Comparison of analyzed skull material (examples) with reconstructions of Metoposaurus diagnosticus, M. krasiejowensis and M. algavrensis skulls.

(A) M. algavrensis. (B) M. krasiejowensis. (C) M. algavrensis. (D) UO/PP02 (Ts2). (E) UO/PP09 (Ts1). (F) UO/PP13 (Ts1). (G) UO/PP04 (Ts1). A-C after Brusatte et al., 2015.

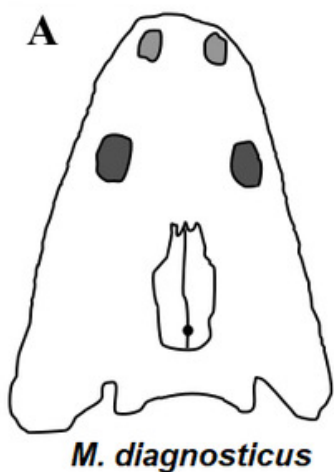

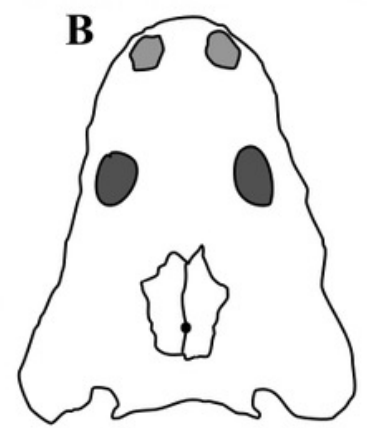

M. krasiejowensis

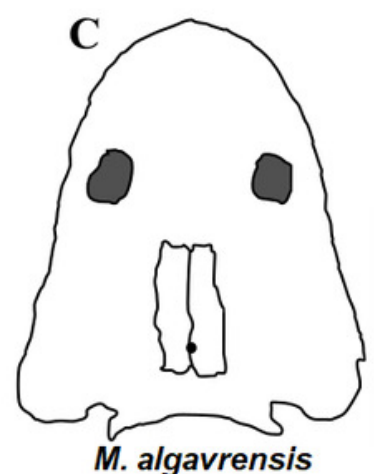

M. algavrensis

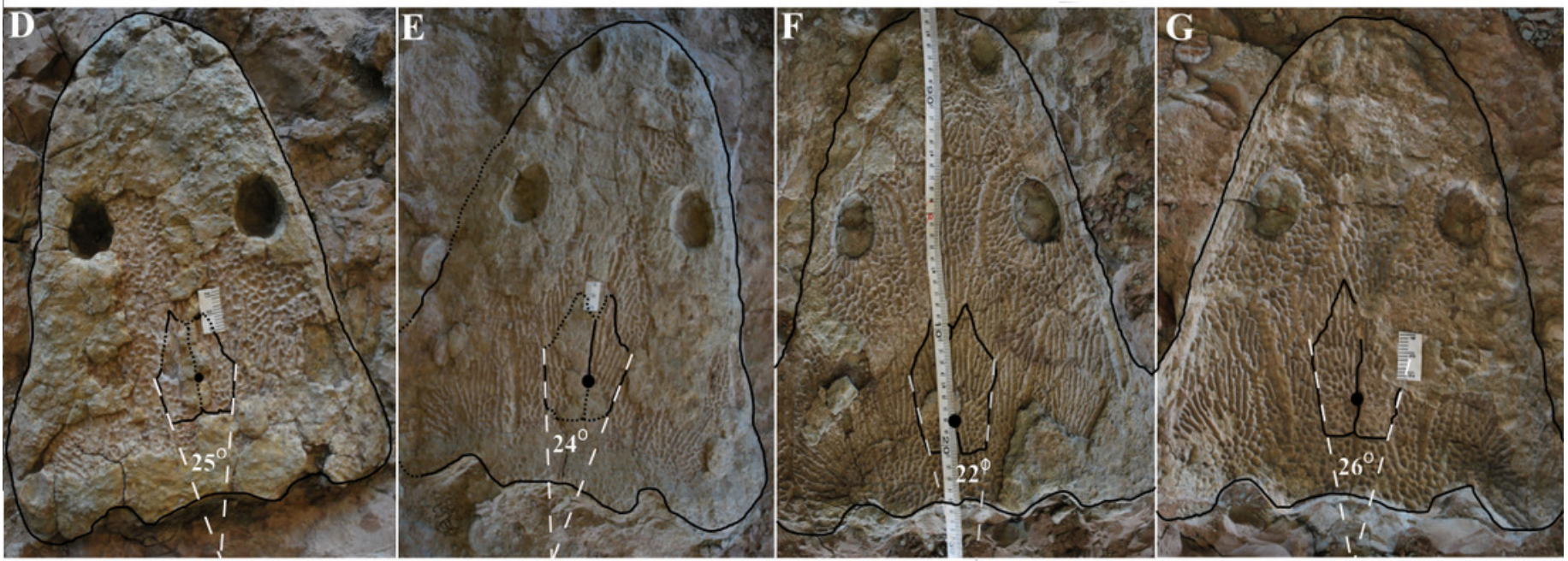


Figure 12

Skull measurements.

A) Skull roof. B) Palate.
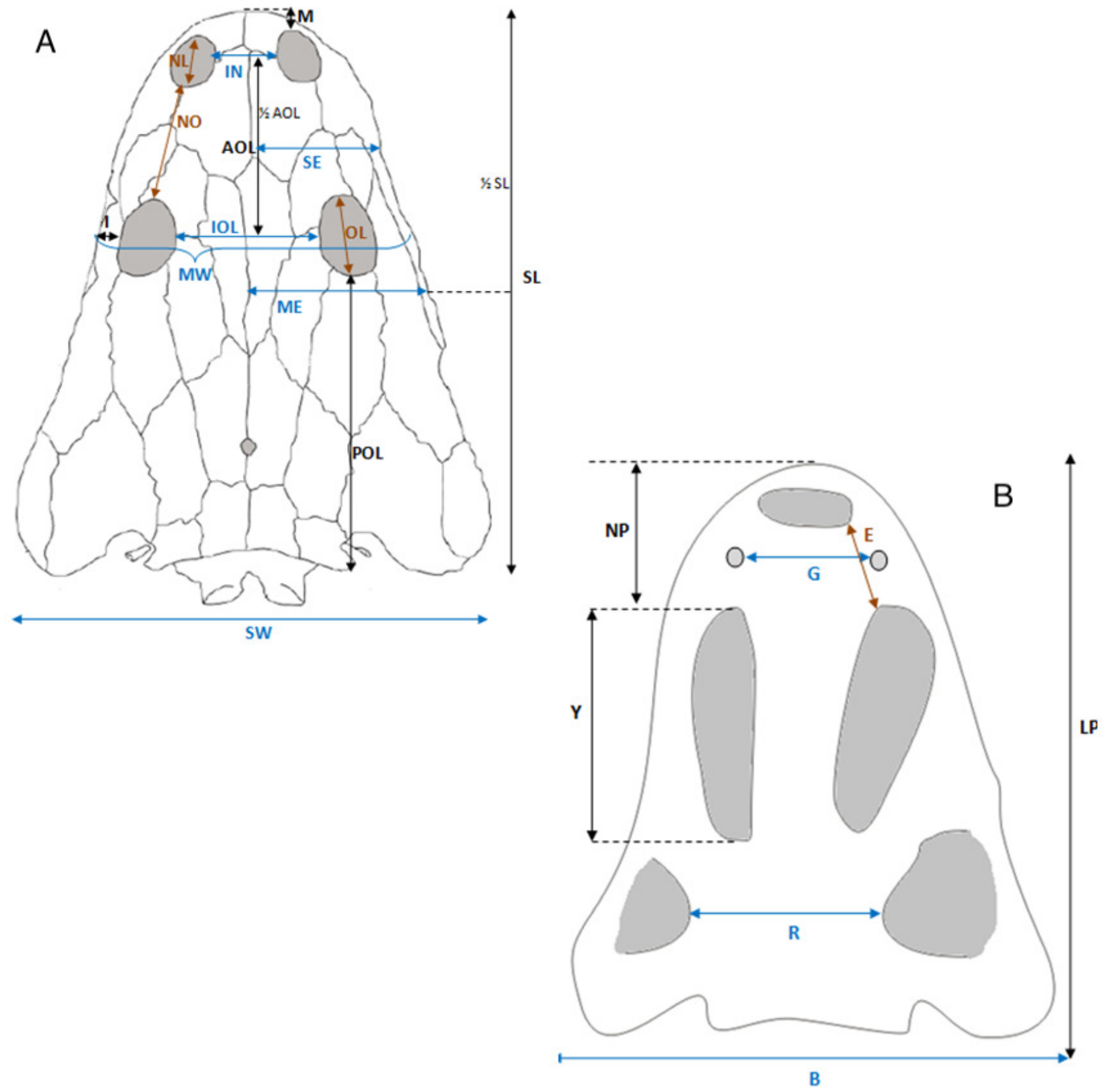


\section{Figure 13}

Ontogenetic stages in clavicles.

Arrows show partition walls and ramifications within radial ridges. (A-C) Ornamentation type 2 (Tc2) from possibly the youngest specimen to the oldest one. (D-F) Ornamentation type 1 (Tc1) from possibly the youngest specimen to the oldest one. (A) UOPB1155. (B) UOPB1168. (C) UOPB1164. (D) UOPB1171. (E) UOPB1166. (F) UOPB1152.

A
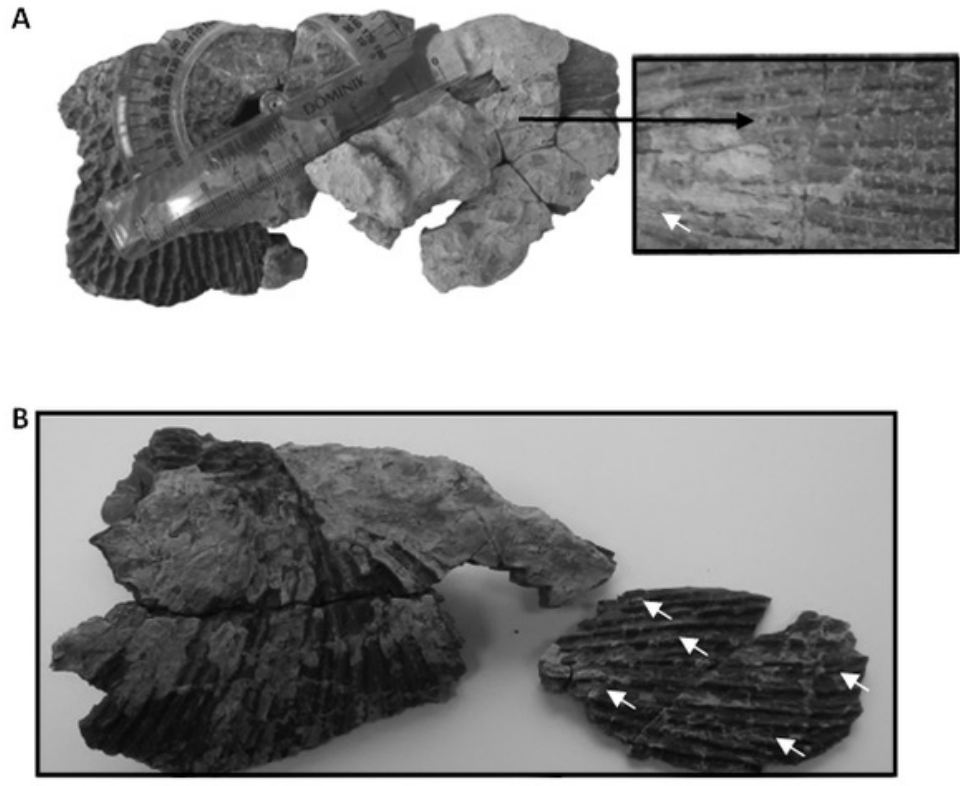

C

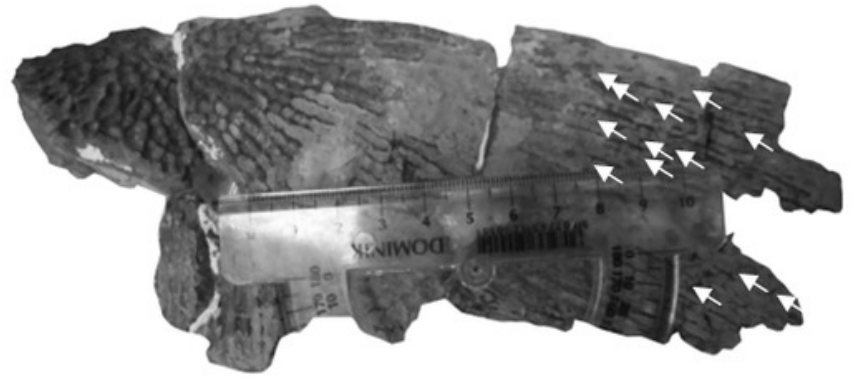

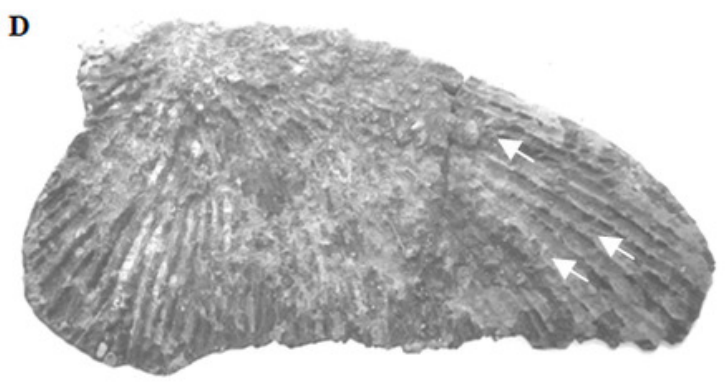
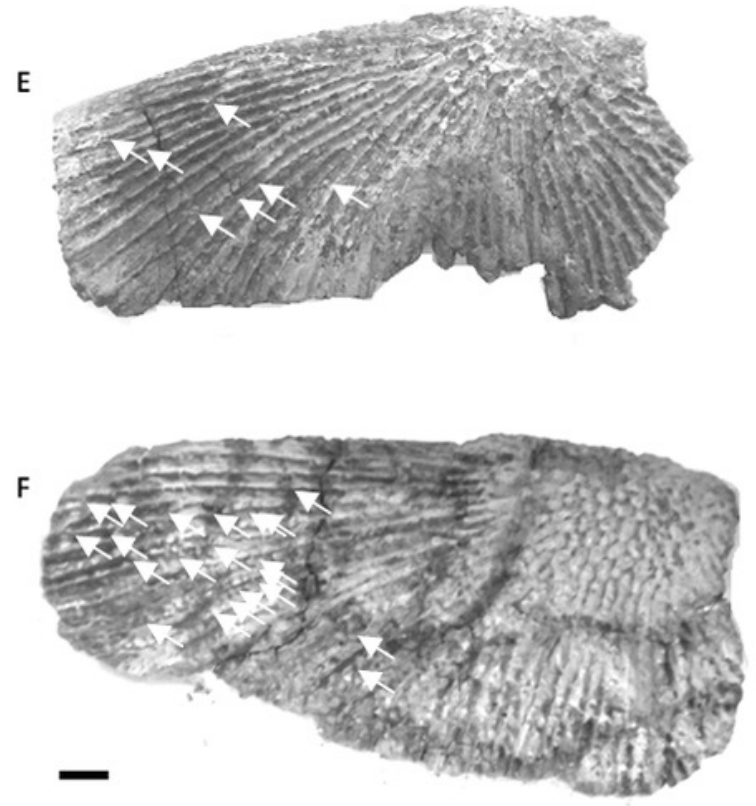
Table $\mathbf{1}$ (on next page)

Clavicles ornamentation 
Very fine (0), fine (1), coarse (2), very coarse (3)

Very sparse (0), sparse (1), dense (2)

\section{Av. polygon}

diameter/av. ridge width $[<4(1),>4(2),>6(3)]$

Distinct borders of

polygonal field (1),

borders partially hard to

recognize (2), hard to
recognize (3)

recognize (3)
Ridge quantity/bone

width [measurement

$2,5 \mathrm{~cm}$ from polygon

border]: $>2,3$ (2), $<2,3$

(1), $<2$ (0)

Nodal points slightly

wider than ridges (1);

some nodal points

distinctly wider than

ridges (2); nodal points

distinctly wider than

ridges (3) [Witzmann et

al. 2010]

Ridges edged (1); round

or edged (2); round (3)

[Witzmann et al. 2010]

Deep polygons (1), deep

or shallow polygons (2)

or shallow polygons (2);
shallow polygons (3) 
Polygon shape: $>50 \%$

hexagons (1), $<50 \%$

hexagons (2), >50\%

quadrangle (3)

Polygon size: usually

small (1), usually large

(2), very large (3) [large:

$>0,4 \mathrm{~mm}$ diameter].

Multipolygons: several

or none (1),

numerous(2) [more

than 11]

Polygon field shape:

square (1), rectangular

(2), elongated (3)

Ridge height: lower

than nodal points (1),

points (2)

Ossification degree: low

(1), high (thick bones)

(2)

Anterior clavicle

projection: small and flat

(1), round and expanded

(2), more than $45 \mathrm{deg}$

(3)

More ramificatios:

opening (1), closing (2)

Shape of the radial

ridges: undulated (1),

straight (2)

Ridge surface

(macroscale): bumps (1),

(3)

Ridge width<half of the

polygon diameter: yes

(1), no (2) (Witzmann et

al. 2010)

Radial ridges

constrictions and height

differences: distinct (1)

not distinct (2)

Shape of the clavicle

(angle) $>100^{\circ}(1),<100^{\circ}$ (2)

$\begin{array}{llll}2 & 2 & 2 & 2\end{array}$

$\begin{array}{lllll}2 & 2 & 2 & 2\end{array}$

10

$\begin{array}{lllll}2 & 3 & 3 & 3 & 3\end{array}$

2

.




\section{PeerJ}


Table 2 (on next page)

SEM observations of the clavicles. 
1 Table 2. SEM observations.

2

\begin{tabular}{|c|c|c|c|c|c|c|c|c|c|c|c|}
\hline & $\begin{array}{l}\text { UOPB } \\
1152\end{array}$ & $\begin{array}{l}\text { UOPB } \\
1153\end{array}$ & $\begin{array}{l}\text { UOPB } \\
1155\end{array}$ & $\begin{array}{l}\text { UOPB } \\
1157\end{array}$ & $\begin{array}{l}\text { UOPB } \\
1160\end{array}$ & $\begin{array}{l}\text { UOPB } \\
1161\end{array}$ & $\begin{array}{l}\text { UOPB } \\
1163\end{array}$ & $\begin{array}{l}\text { UOPB } \\
1164\end{array}$ & $\begin{array}{l}\text { UOPB } \\
1167\end{array}$ & $\begin{array}{l}\text { UOPB } \\
1168\end{array}$ & $\begin{array}{l}\text { UOPB } \\
1169\end{array}$ \\
\hline $\begin{array}{l}\text { Roughness } \\
{[\mathrm{v}-\text { distinct }} \\
\mathrm{x}-\text { not distinct }]\end{array}$ & $x$ & $\mathrm{~V}$ & $\mathrm{~V}$ & $\mathrm{~V}$ & $\mathrm{~V}$ & $\mathrm{~V}$ & $\mathrm{~V}$ & $\mathrm{~V}$ & $\mathrm{x}$ & $\mathrm{V}$ & $\mathrm{V}$ \\
\hline $\begin{array}{l}\text { Striations } \\
{[\mathrm{v}-\text { distinct, numerous }} \\
\mathrm{x}-\text { few }]\end{array}$ & $\mathrm{x}$ & $\mathrm{V}$ & $\mathrm{V}$ & $\mathrm{V}$ & $\mathrm{X}$ & $x$ & $\mathrm{~V}$ & & $x$ & $\mathrm{~V}$ & $\mathrm{~V}$ \\
\hline $\begin{array}{l}\text { Small foramina } \\
{\left[\mathrm{v} \text {-more than } 7 / 100 \mathrm{um}^{2}\right.} \\
\left.\mathrm{x} \text { - less than } 7 / 100 \mathrm{um}^{2}\right]\end{array}$ & $\mathrm{X}$ & $\mathrm{V}$ & $\mathrm{V}$ & $\mathrm{V}$ & $\mathrm{X}$ & $\mathrm{X}$ & $\mathrm{V}$ & $\mathrm{V}$ & $\mathrm{X}$ & $\mathrm{V}$ & $\mathrm{V}$ \\
\hline $\begin{array}{l}\text { Large foramina } \\
{[\mathrm{v}-\text { more than } 1 / 1 \mathrm{~mm} \text { of length }} \\
\mathrm{x}-\text { less than } 1 / 1 \mathrm{~mm} \text { of length }]\end{array}$ & $\mathrm{X}$ & $\mathrm{X}$ & $\mathrm{V}$ & $\mathrm{V}$ & $\mathrm{X}$ & $\mathrm{V}$ & $\mathrm{V}$ & $\mathrm{V}$ & $\mathrm{x}$ & $\mathrm{V}$ & $\mathrm{X}$ \\
\hline
\end{tabular}


Table $\mathbf{3}$ (on next page)

Skulls ornamentation characteristcs. 
1 Table 3. Skulls ornamentation.

\begin{tabular}{|c|c|c|c|c|c|c|c|c|c|c|c|c|c|c|c|}
\hline \multirow{3}{*}{$\begin{array}{l}\text { Parietal- } \\
\text { supratemporal } \\
\text { ornament } \\
\text { Postfrontal- } \\
\text { postorbital } \\
\text { ornament }\end{array}$} & & $\mathrm{UO} / \mathrm{PP} 01$ & UO/PP02 & UO/PP04 & UO/PP06 & UO/PP08 & UO/PP09 & UO/PP12 & UO/PP13 & UO/PP14 & UO/PP16 & UO/PP17 & UO/PP18 & UO/PP20 & $\mathrm{uam} / \mathrm{mz}$ \\
\hline & $\begin{array}{l}\text { polygons (2), } \\
\text { radial ridges } \\
\text { (1) }\end{array}$ & & 2 & 1 & 1 & 2 & 1 & 2 & 1 & 1 & 2 & 1 & 2 & 2 & 1 \\
\hline & $\begin{array}{l}\text { Mostly: } \\
\text { polygons (3), } \\
\text { Polygons and } \\
\text { radial ridges } \\
\text { (2), radial } \\
\text { ridges (1) }\end{array}$ & & 3 & 2 & 1 & 3 & 2 & 3 & 2 & & 2 & 2 & 3 & 3 & 2 \\
\hline $\begin{array}{l}\text { Squamosal } \\
\text { ornament }\end{array}$ & $\begin{array}{l}\text { Mostly: } \\
\text { polygons (2), } \\
\text { radial ridges } \\
\text { (1) }\end{array}$ & 1 & 1 & 1 & & & 1 & 1 & 1 & & 1 & 1 & & & 1 \\
\hline \multirow{3}{*}{$\begin{array}{l}\text { Multipolygons } \\
\text { Polygon shape }\end{array}$} & $\begin{array}{l}\text { Occurs (2), } \\
\text { not occur (1) }\end{array}$ & & 2 & 1 & & & & 2 & 1 & & 2 & 2 & & & 1 \\
\hline & & & & & & & & & & & & & & & \\
\hline & $\begin{array}{l}\text { Irregular (2), } \\
\text { mostly } \\
\text { hexagonal (1) }\end{array}$ & 2 & 2 & 1 & & 2 & 1 & 2 & 1 & 1 & 2 & 1 & 2 & 2 & 1 \\
\hline Polygon size & $\begin{array}{l}\text { Small (2), } \\
\text { large (1) }\end{array}$ & & 2 & 2 & & 2 & 1 & 2 & 1 & 2 & 2 & 1 & 2 & 2 & 2 \\
\hline Polygon den sity & $\begin{array}{l}\text { Sparse (1), } \\
\text { dense (2) }\end{array}$ & & 2 & 1 & & 2 & 1 & 2 & 1 & $\mathrm{x}$ & 2 & $\mathrm{x}$ & 2 & 2 & 1 \\
\hline \multicolumn{16}{|l|}{2} \\
\hline \multicolumn{16}{|l|}{3} \\
\hline \multicolumn{16}{|l|}{4} \\
\hline 5 & & & & & & & & & & & & & & & \\
\hline
\end{tabular}




\section{Table 4(on next page)}

Skull measurements [in $\mathrm{cm}$ ]. 
Table 4. Skull measurements [in cm].

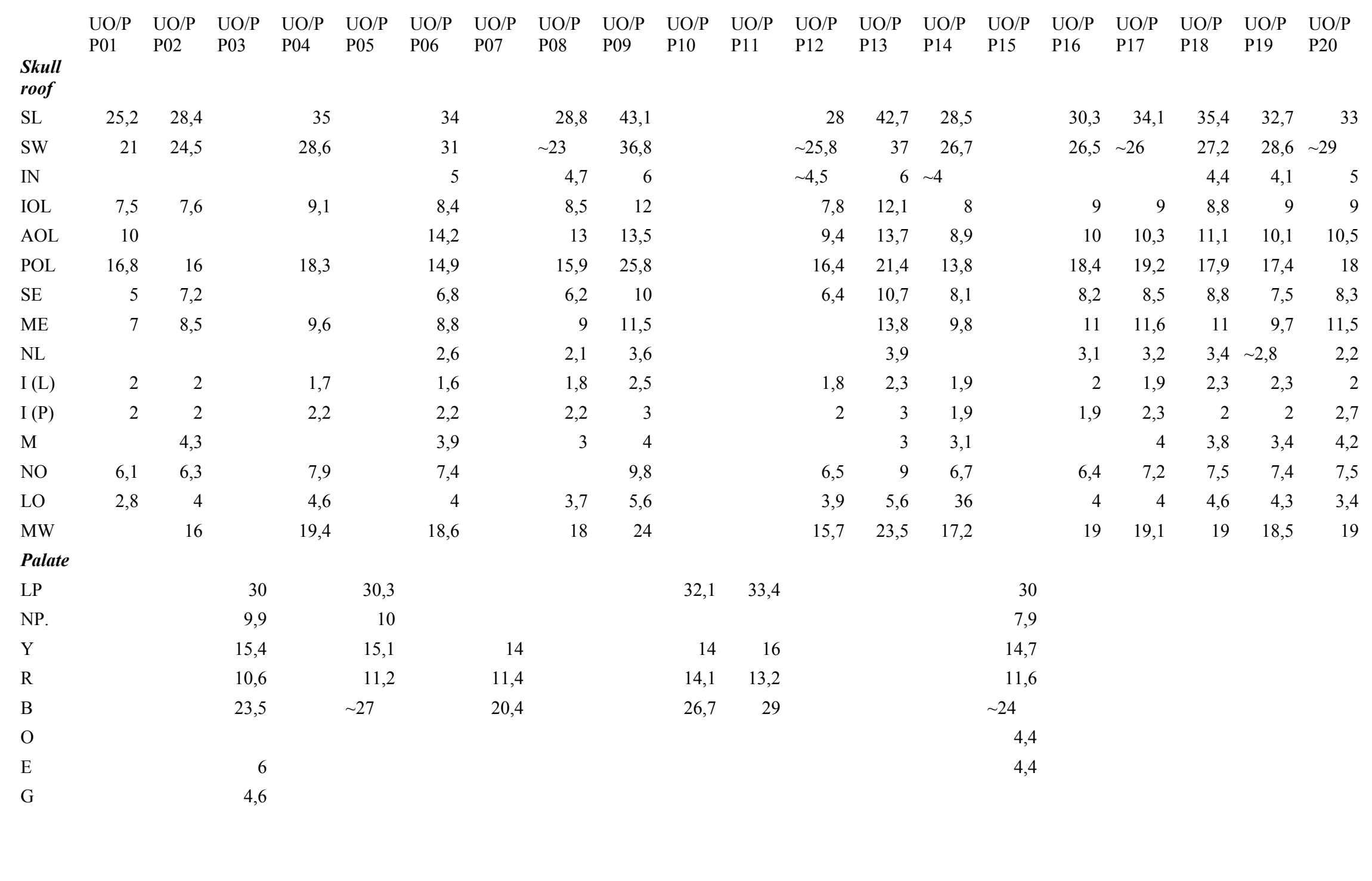




\section{Table 5 (on next page)}

Statistical tests. 
1 Table 5. Statistical tests.

2

\begin{tabular}{|c|c|c|c|}
\hline & \multicolumn{2}{|c|}{ p-value } \\
\hline & & T1 & $\mathrm{T} 2$ \\
\hline \multirow{3}{*}{$\begin{array}{c}\text { av. polygon } \\
\text { diameter/av. ridge } \\
\text { width }\end{array}$} & Shapiro-Wilk Test & 0,55655 & 0,24746 \\
\hline & Test F & \multicolumn{2}{|c|}{0,321792} \\
\hline & Test T & \multicolumn{2}{|c|}{0,00106} \\
\hline \multirow{2}{*}{$\begin{array}{l}\text { multipolygon } \\
\text { number }\end{array}$} & Shapiro-Wilk Test & 0,146977 & 0,04937 \\
\hline & Test U & \multicolumn{2}{|c|}{0,001676} \\
\hline \multirow{2}{*}{$\begin{array}{c}\text { ridge } \\
\text { number/bone } \\
\text { width } \\
\end{array}$} & Shapiro-Wilk Test & 0,0703221 & 0,010253 \\
\hline & Test U & \multicolumn{2}{|c|}{0,035556232} \\
\hline \multirow[t]{2}{*}{ qualitative data } & Shapiro-Wilk Test & $2,587 \mathrm{E}-07$ & 0,541135 \\
\hline & Test U & \multicolumn{2}{|c|}{0,000194} \\
\hline
\end{tabular}

3 


\section{Table 6(on next page)}

Diagnosis and remarks on two populations of $M$. krasiejowensis. 
2 Table 6. Diagnosis and remarks on two populations of M. krasiejowensis.

\begin{tabular}{|c|c|c|}
\hline & Type 1 & Type 2 \\
\hline \multirow{10}{*}{ 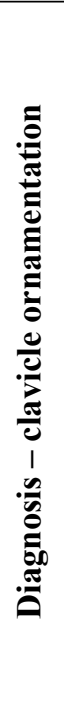 } & Less numerous radial ridges & More numerous radial ridges \\
\hline & Smaller ossification degree & Higher ossification degree \\
\hline & Regular and fine ornamentation & Irregular and coarse ornamentation \\
\hline & Sparse ornamentation & Gęsta ornamentacja kości skórnych \\
\hline & Mostly hexagonal polygons & Mostly pentagonal (and other) polygons \\
\hline & Few multipolygons & Numerous multipolygons \\
\hline & $\begin{array}{l}\text { Distinct border of ossification centre, } \\
\text { square ossification centre }\end{array}$ & $\begin{array}{l}\text { Border of ossification centre difficult to } \\
\text { distinct, elongated ossification centre }\end{array}$ \\
\hline & $\begin{array}{l}\text { Polygonal ornamentation covering } \\
\text { smaller area }\end{array}$ & $\begin{array}{l}\text { Polygonal ornamentation covering larger } \\
\text { area }\end{array}$ \\
\hline & $\begin{array}{l}\text { Less numerous microforamina and } \\
\text { striations on the radial ridges }\end{array}$ & $\begin{array}{l}\text { More numerous microforamina and } \\
\text { striations on the radial Bridges }\end{array}$ \\
\hline & $\begin{array}{l}\text { Growth Marks in close proximity within } \\
\text { al most avascular upper cortex }\end{array}$ & $\begin{array}{l}\text { Growth Marks separated by vascularised } \\
\text { zones }\end{array}$ \\
\hline \multirow{3}{*}{ 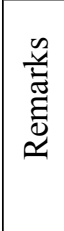 } & $\begin{array}{l}\text { Mostly radial ornamentation in the postorbital part } \\
\text { of the skull }\end{array}$ & $\begin{array}{l}\text { Mostly polygonal ornamentation in the postorbital } \\
\text { part of the skull }\end{array}$ \\
\hline & Larger skulls & Smaller skulls \\
\hline & \multicolumn{2}{|c|}{$\begin{array}{l}\text { Two growth patterns seen in femora and humeri (Konietzko-Meier and Klein, 2013; } \\
\text { Teschner, Sander \& Konietzko-Meier, 2017) }\end{array}$} \\
\hline
\end{tabular}

